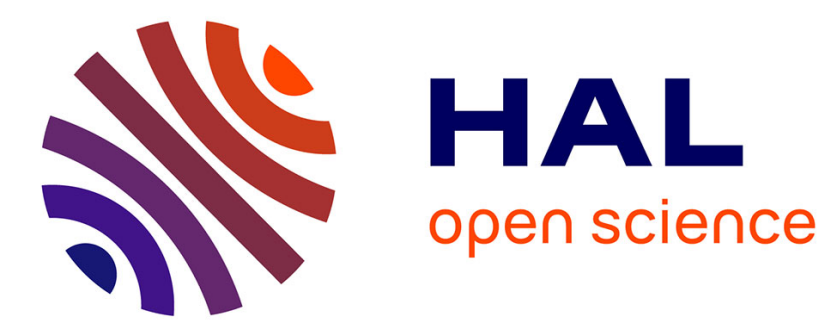

\title{
CPU-FPGA based real-time simulation of fuel cell electric vehicle
}

Rui Ma, Chen Liu, Zhixue Zheng, Franck Gechter, Pascal Briois, Fei Gao

\section{To cite this version:}

Rui Ma, Chen Liu, Zhixue Zheng, Franck Gechter, Pascal Briois, et al.. CPU-FPGA based real-time simulation of fuel cell electric vehicle. Energy Conversion and Management, 2018, 174, pp.983-997. 10.1016/j.enconman.2018.08.099 . hal-02495991

\section{HAL Id: hal-02495991 https://hal.science/hal-02495991}

Submitted on 21 Apr 2020

HAL is a multi-disciplinary open access archive for the deposit and dissemination of scientific research documents, whether they are published or not. The documents may come from teaching and research institutions in France or abroad, or from public or private research centers.
L'archive ouverte pluridisciplinaire HAL, est destinée au dépôt et à la diffusion de documents scientifiques de niveau recherche, publiés ou non, émanant des établissements d'enseignement et de recherche français ou étrangers, des laboratoires publics ou privés. 


\title{
CPU-FPGA based real-time simulation of fuel cell electric vehicle
}

\author{
Rui Ma ${ }^{\mathrm{a}, *}$, Chen Liu ${ }^{\mathrm{b}, \mathrm{c}}$, Zhixue Zheng ${ }^{\mathrm{b}, \mathrm{c}}$, Franck Gechter ${ }^{\mathrm{d}}$, Pascal Briois ${ }^{\mathrm{e}}$, Fei Gao ${ }^{\mathrm{b}, \mathrm{c}}$ \\ a School of Automation, Northwestern Polytechnical University, 710072 Xi'an, China \\ ${ }^{\mathrm{b}}$ FEMTO-ST (UMR CNRS 6174), Energy Department, Univ. Bourgogne Franche-Comté, UTBM, F-90010 Belfort Cedex, France \\ ${ }^{\mathrm{c}}$ FCLAB (FR CNRS 3539), Univ. Bourgogne Franche-Comté, UTBM, Rue Thierry Mieg, F-90010 Belfort Cedex, France \\ d Le2i (UMR CNRS 6306), Univ. Bourgogne Franche-Comté, UTBM, F-90010 Belfort Cedex, France \\ e FEMTO-ST (UMR CNRS 6174), MN2S Department, Univ. Bourgogne Franche-Comté, UTBM, 25200 Montbéliard, France
}

Proton exchange membrane fuel cell (PEMFC) has been considered as one of the promising renewable power technologies for the vehicular application. This paper proposes a fuel cell electric vehicle (FCEV) power system model that can be implemented in the hardware-in-the-loop (HIL) emulation for real-time execution on fieldprogrammable gate arrays (FPGAs). The FCEV model comprises three parts: a PEMFC, a Z-source inverter and a squirrel cage motor. To achieve an accurate and efficient FPGA resources' utilization, the PEMFC model is implemented by CPU whereas the models of the DC-AC inverter and the electrical motor are built in FPGA. For the validation of the proposed power system, the real-time simulation tests are conducted with a high accuracy. The developed hybrid system model can reach a simulation time step of $100 \mathrm{~ns}$ for FPGA and $500 \mu$ s for CPU under the co-simulation mode. Moreover, the simulation under various system operating conditions indicates that the high performance can be reached by the hybrid system computed in real-time. The proposed real-time model can be used to design the on-line diagnostic and model predictive control method, which can help to test the FCEV before the commercial applications.

\section{Introduction}

Proton Exchange Membrane fuel cells (PEMFCs) can transform the chemical energy stored in hydrogen fuel into electricity directly without pollution, which have received significant research attention in both laboratory and industrial field. Along with the depletion of traditional fossil fuel, the conventional oil and diesel vehicles need to find a replaced fuel for propulsion. Thanks to the advancement of the fuel cell material in recent years, the power of PEMFC can meet the requirement of vehicular applications. Thus, the research attention has been refocused on the modeling of the fuel cells. Conventional fuel cell models can be classified by the modeling dimension and the modeling domain. Different models may vary from zero-dimensional (OD) to three-dimensional (3D), which can couple electrochemical, fluidic and thermal domains. A complex fuel cell model accounts for a higher accuracy, whereas for the vehicular applications, the basic equivalent circuit models are usually adopted due to the simplicity.

Fuel cell models proposed in literature [1-6] give the basic equivalent circuit models for the PEMFC, which can be applied for fuel cell electric vehicle (FCEV) modeling and simulation. These models can be used for verifying the polarization characteristics of the fuel cell, whereas the modeling approach may lose some accuracy. For improving the accuracy of the fuel cell model, literature [7-12] are focused on the multi-physical approach. These models are useful for analyzing the fuel cell operating in the vehicular applications, especially for the degradation phenomenon since the fuel cell temperature can vary a lot when a larger load is required. As it is known, the lifespan can be a key factor for the fuel cell electric vehicle (FCEV). The temperature variation can influence the fuel cell performance seriously by decreasing the lifespan. In order to better control and investigate the fuel cell degradation on FCEVs, multi-physical model including thermal phenomenon should be considered during the modeling of FCEV.

Aside of the fuel cell model, the modeling of the power converter is also very important since the efficiency and stability can greatly influence the performance of the EV system. Modeling works [13-18] on FCEV contribute to the developing and analyzing of the power converter before FCEV's mass commercial implementation. Das et al. [13] gives a comprehensive conclusion of the latest power conditioning units and topologies of the fuel cell hybrid electric vehicles. Different types of power converters are analyzed and compared in the paper, leading to different control techniques applied to different power stage demands. Articles [14-16] give the stabilization and energy management analysis

\footnotetext{
* Corresponding author.

E-mail address: rui.ma@utbm.fr (R. Ma).
} 
of the power converter for FCEV system. The test of dynamic load variation is discussed, and the converter can maintain the power output in an effectively way. However, the fuel cell models used are constrained to the equivalent circuit model, which will certainly lose some accuracy of the modeling system. Literature $[17,18]$ are all related to interleaved DC-DC converter for fuel cell vehicle applications. The proposed converters work under different control algorithms to maintain the power supply of the machine and can decrease the input current ripple for improving the efficiency and reliability. However, none of the proposed models can be applied directly to the real-time simulation due to the utilization of the simulation modules in the commercial software.

Hardware-in-the-loop (HIL) applications can provide a time-saving and safe way for designing the on-line control method, which can be used to evaluate FCEV performance before its commercial spreading around the world. However, few researches [19-22] are focused on the real-time simulation of the FCEV. Since a typical FCEV system couples a high non-linear characteristic, and the multi-physical fuel cell dynamic performance among different domains can make the system hard to be executed in real-time. Moreover, CPU-based simulation might suffer from the high I/O latency and thus make the power electronic system in FCEV hard to keep accurate and stable due to the multi-switch events introduced by the PWM control strategy. Literature [19] contributes to the analysis of two real-time optimization strategies for a PEMFC system, which is used as the power source of the hybrid FCEV. The control and management algorithms are discussed in detail in the paper, whereas the converter and the machine are not discussed. A PEMFC vehicle real-time platform has been built using dSPACE simulator in [20]. The developed real-time model for FCEV can operate under constant load conditions, and the simulation results are validated by the experiment, whereas the fuel cell model is still of an equivalent circuit one. For better applying the power management strategy, a realtime fuzzy logic power management strategy for a fuel cell vehicle is proposed in [21]. The paper analyzes and evaluates the performance of the three operating parts including a fuel cell, a battery and a super capacitor, whereas the fuel cell model in the proposed system takes into consideration only the electrochemical domain. Research [22] tests the real-time performance of the fuel cell model and power converter on the FCEV, whereas the system involves no electrical part and is not capable to assess the overall performance of FCEV.

The main objects of this paper focus on building a hardware-in-theloop (HIL) simulation platform to evaluate the overall FCEV performance. As it can be seen from Fig. 1, the simplified FCEV power system contains three parts [13]: the fuel cell as the input power source, the $\mathrm{Z}$ source inverter as the power transmission and the three-phase AC machine as the load. By combining the fuel cell model, the power converter and the AC machine together, a basic FCEV power system can be formulated to verify the overall system performance. In order to verify the power converter stability, dynamic inputs through the multi-physical fuel cell model under various operating conditions are conducted. Moreover, the proposed FCEV model can operate under co-simulation mode through the FPGA and CPU. By deploying the CPU to solve the high-order equations in the fuel cell model, we can study the different physical characteristics of fuel cell under the influence power electronic converter. With the power electronic system implemented in the FPGA, we can get a high-speed calculation model with consideration of fuel cell model. Meanwhile, the developed model can be used to monitor the fuel cell operating performance and design the on-line diagnostic control methods of the FCEV. The model can also provide insights to the converter and electrical motor control strategy research. The principle contributions of this paper include:

1. A multi-physical fuel cell model including electrochemical, fluidic and thermal domains is developed for FCEV to operate under various operating conditions;

2. The implementation of power converter associating with an asynchronous motor in the FPGA could provide the controller a low I/O latency;

3. Real-time simulation for a FCEV powertrain system is conducted with a time step of $50 \mathrm{~ns}$ for FPGA and a time step of $500 \mu$ s for CPU, which can help to develop the on-line diagnostic and control method.

The following of this paper are organized as follows: Section 2 gives the multi-physical fuel cell model, which takes into consideration the electrochemical, fluidic and thermal domains. The converter and electric machine models are developed in Section 3. In Section 4, the algorithms for the hybrid system are discussed and analyzed. Section 5 gives the simulation results for the proposed power model. A conclusion section is finally presented in Section 6.

\section{Multi-physical fuel cell modeling}

In this section, the multi-physical PEMFC model will be demonstrated in electrochemical, fluidic and thermal domains, respectively. During the operating of the fuel cell, the degradation occurs and the overall performance of the fuel cell system can be influenced. In most cases, degradation mechanisms in PEMFC for transportation applications are: carbon corrosion, catalyst sintering and membrane degradation. As indicated by the reviewer, these degradation mechanisms can be highly influenced and accelerated by the operating conditions such as load cycling, thermal cycling and start-stop conditions. For this topic, the degradation related phenomenon for fuel cell has been discussed in our previous related works [33-35]. Since this work our main contribution is the realization of the real-time capable model and HIL simulation for the fuel cell electric vehicle applications using separate

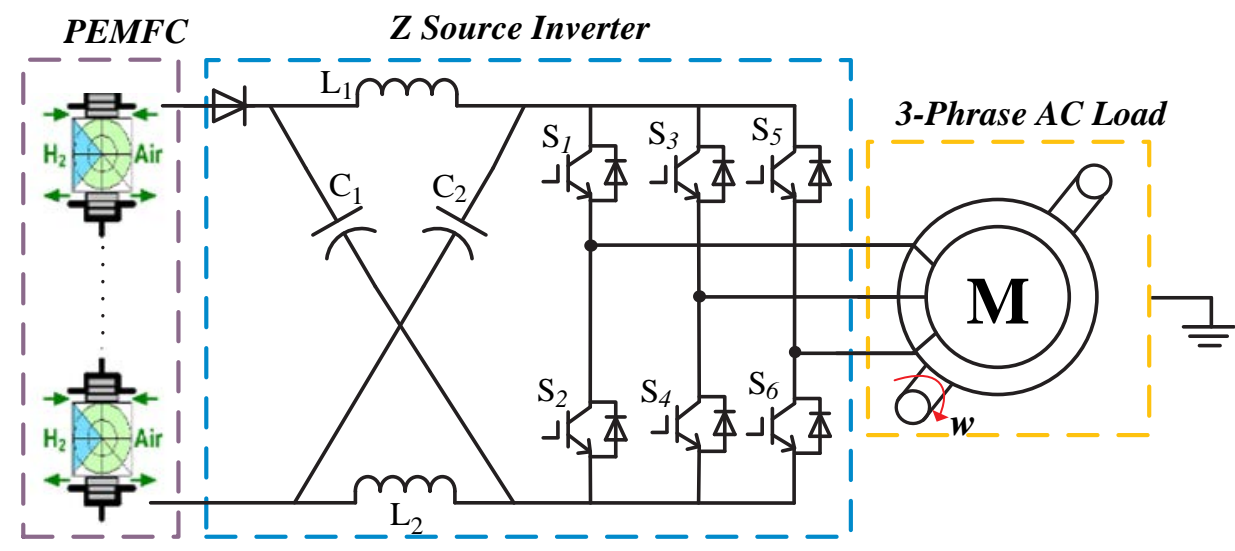

Fig. 1. FCEV power system with Z Source inverter. 
processors include CPU and FPGA, the degradation related analysis will not be demonstrated.

\subsection{Electrochemical domain}

The fuel cell polarization curve can be used to describe the output voltage under a given current, which can indicate the electrochemical performance for certain operating conditions. The fuel cell output voltage can be expressed as:

$V_{\text {Cell }}=E_{\text {ele }}-V_{\text {act }}-V_{\text {ohm }}-V_{\text {conc }}$

where $E_{\text {ele }}$ is the fuel cell electromotive force (V), $V_{\text {act }}$ is the activation voltage loss $(\mathrm{V}), V_{\text {ohm }}$ represents the ohmic voltage loss $(\mathrm{V})$ of the electrode-electrolyte assemblies, and $V_{\text {conc }}$ is the concentration loss (V). It should be noted that the concentration losses in a fuel cell are due to the pressures drop through the gas diffusion layer (GDL). In the proposed model, the pressures of the species at the catalyst layer can be directly obtained due to the fluidic model presented hereafter. Thus, the term of the concentration losses is not necessary in (1) for this model.

The electromotive force $E_{\text {ele }}$ can be defined by the Nernst equation accompanied with the Gibbs free energy changes from the reactants to products:

$E_{\text {ele }}=E_{\text {rev }}-0.00085(T-298.15)+\frac{R T}{2 F} \ln \left(P_{\mathrm{H}_{2}} \sqrt{P_{\mathrm{O}_{2}}}\right)$

where $E_{\text {rev }}=1.229$ is the reversible nearest potential for single cell (V), $T$ represents the temperature at the reaction sites $(\mathrm{K}), P_{\mathrm{H}_{2}}$ and $P_{\mathrm{O}_{2}}$ are the hydrogen gas pressure and oxygen gas pressure at the reaction sites (atm), respectively, $F=96485.3$ is the Faraday constant $(\mathrm{C} / \mathrm{mol})$, $R=8.314$ is the universal gas constant $(\mathrm{J} /(\mathrm{mol} \cdot \mathrm{K}))$.

The steady-state activation voltage $V_{a c t}$ can be expressed by the Butler-Volmer equation [22]:

$i=j_{0} A_{e l}\left[\exp \left(\frac{\alpha n_{e} F}{R T} V_{a c t}\right)-\exp \left(\frac{\beta n_{e} F}{R T} V_{a c t}\right)\right]$

where $i$ is the current of the fuel cell (A), $A_{e l}$ is the area of the electrode $\left(\mathrm{m}^{2}\right), j_{0}$ is the exchange current density $\left(\mathrm{A} / \mathrm{m}^{2}\right), n_{e}$ is the electrons number involved in the half reactions at anode or cathode, $\alpha, \beta$ are symmetry factors.

The ohmic voltage is generally due to the resistance of the membrane electrolyte, whereas the contact resistance between interfaces is often ignored. The ohmic voltage can be obtained through Joule's law by the following equation:

$V_{\text {ohm }}=i \cdot R_{\text {mem }}=\frac{i}{A_{e l}} \int_{0}^{\delta_{e l}} r(T, \lambda(z)) d z$

where $\delta_{e l}$ is the thickness of the membrane electrolyte (m), $r(T, \lambda(z))$ is the membrane local resistivity $(\Omega \cdot \mathrm{m})$, which can be obtained as [23]:

$r(T, \lambda)=\left\{\begin{array}{cc}\frac{1}{0.1933} e^{\left[1268\left(\frac{1}{T}-\frac{1}{303}\right)\right],} & 0<\lambda<1 \\ \frac{1}{0.5193 \lambda-0.326} e^{\left[1268\left(\frac{1}{T}-\frac{1}{303}\right)\right],} & \lambda>1\end{array}\right.$

where $\lambda(z)$ is the local water content of the membrane. [22]:

In the membrane layer, the water content can be written as follows

$\lambda=\left\{\begin{array}{c}0.0043+17.81 \cdot a_{\mathrm{H}_{2} \mathrm{O}}-39.85 \cdot a_{\mathrm{H}_{2} \mathrm{O}}^{2}+36 \cdot a_{\mathrm{H}_{2} \mathrm{O}}^{3}, \quad\left[0<a_{\mathrm{H}_{2} \mathrm{O}} \leq 1\right] \\ 14+1.4 \cdot\left(a_{\mathrm{H}_{2} \mathrm{O}}-1\right), \quad\left[0<a_{\mathrm{H}_{2} \mathrm{O}} \leq 3\right]\end{array}\right.$

where $a_{\mathrm{H}_{2} \mathrm{O}}$ is the water activity, calculated from the partial water vapor pressure $P_{\mathrm{H}_{2} \mathrm{O}}(\mathrm{Pa})$, and the water saturation pressure $P_{\text {sat }}(\mathrm{Pa})$.

\subsection{Fluidic domain}

During the PEMFC operation, the mixed gas flow in the channel leads to the pressure drop along the flow direction. The reactant diffusion from channel to the reaction sites is caused by the concentration gradient at two sides of the electrode.

The fluidic dynamic phenomenon in the fuel cell gas channel can be described by the mass conservation equation:

$\frac{\mathrm{d}}{\mathrm{dt}} P_{\text {gas }, c h}=\frac{R T}{M_{\text {gas }} V_{\text {ch }}} \cdot \sum_{\text {in/out }}^{c h} q_{\text {gas }}$

where $V_{c h}$ represents the volume of the gas channel $\left(\mathrm{m}^{3}\right), M_{g a s}$ is the molar mass of the gas components $(\mathrm{kg} / \mathrm{mol}), P_{\text {gas }, c h}$ is the gas pressure in the channel (Pa), and the last term $q_{\text {gas }}$ stands for the molar gas flow rate entering and leaving the gas channel $(\mathrm{kg} / \mathrm{s})$.

The flow through the gas channel is considered to be laminar. The gas pressure drop along the channel can thus be calculated by Darcy-Weisbach equation [23] as:

$\Delta P=32 \rho_{g a s} \frac{L v^{2}}{D_{c h} R e}$

where $\rho_{\text {gas }}$ is the gas mixture density $\left(\mathrm{kg} / \mathrm{m}^{3}\right), D_{\text {ch }}$ accounts for the tube hydraulic diameter $(\mathrm{m})$, which equals to the internal diameter of the tube for the studied PEMFC, vis the mean flow velocity (m/s), $L$ is the length of the tube (m), Re is the Reynolds number.

The reactant gas diffusion in the electrode is directly related to the fuel cell current as follows:

$q_{\text {gas }}=\frac{i}{n_{e} F}$

Sometimes, the fuel gas contains not only hydrogen, vapor and oxygen, but also Nitrogen gas which is used as a non-reactant gas to ensure the same total gas pressure when the molar fraction of other gas changes. The diffusion of each species of the mixed gas in the electrodes can be expressed by the Stefan-Maxwell equation [23]:

$\Delta P_{i}=\frac{4 R T \delta_{e l}}{\pi P_{g a s} D_{c h}^{2}} \sum_{i \neq j} \frac{P_{i}\left(q_{j} / M_{j}\right)-P_{j}\left(q_{i} / M_{i}\right)}{D_{i j}}$

where $P_{g a s}$ is the total pressure of the gas in the electrode (Pa), $D_{i j}$ stands for the binary diffusion coefficient between fuel gas species $i$ and $j\left(\mathrm{~m}^{2} /\right.$ s).

Moreover, the water balance in the membrane layer can be described by two different phenomena: the electroosmotic drug described by $J_{d r a g}$ and the back diffusion described by $J_{b d}$ :

$J_{\text {drag }}=\frac{n_{\text {sat }}}{11} \cdot \frac{\lambda_{A}+\lambda_{C}}{2} \cdot \frac{i}{2 F} \cdot M_{\mathrm{H}_{2} \mathrm{O}}$

$J_{b d}=\frac{\rho_{d r y}}{M_{n}} \cdot D_{\lambda} \cdot \frac{\lambda_{A}-\lambda_{C}}{\delta_{m e m}} \cdot A_{e l} \cdot M_{\mathrm{H}_{2} \mathrm{O}}$

where $n_{\text {sat }}=22$ is the electroosmotic drag coefficient for maximum hydration condition, $\rho_{d r y}$ is the dry density of the membrane $\left(\mathrm{kg} / \mathrm{m}^{3}\right)$, $D_{\lambda}$ is the mean water diffusion coefficient in the membrane $\left(\mathrm{m}^{2} / \mathrm{s}\right), \delta_{\text {mem }}$ is the membrane thickness $(\mathrm{m}), \lambda_{A}$ and $\lambda_{C}$ are the membrane water contents at the anode side and cathode side, respectively, and $M_{n}$ is the equivalent mass of the membrane $(\mathrm{kg} / \mathrm{mol})$.

The total water mass flow $(\mathrm{kg} / \mathrm{s})$ in the membrane can be then expressed as [22]:

$q_{\mathrm{H}_{2} \mathrm{O}, \mathrm{mem}}=J_{\text {drag }}+J_{b d}$

\subsection{Thermal domain}

Thermal characteristics analysis is of great importance for the fuel cell operation. The proposed fuel cell thermal model is developed for each cell layers including cooling layer, gas channel layer, GDL, catalyst layer and membrane layer by the control volume approach (CV). Different CVs have various boundaries, which should be taken into consideration in the model. The thermal governing equations is given 
by:

$\frac{\mathrm{d}}{\mathrm{dt}} T_{\text {cell }}=\left(Q_{m}+Q_{f c}+Q_{c d}+Q_{\text {nar }}+Q_{i n t}\right) /\left(\rho_{C V} V_{C V} C_{p}\right)$

where $T_{\text {cell }}$ represents the temperature of the fuel cell (K), $\rho_{C V}$ is the mean density of the fuel cell CV $\left(\mathrm{kg} / \mathrm{m}^{3}\right), V_{C V}$ stands for the volume for the fuel cell $\mathrm{CV}\left(\mathrm{m}^{3}\right), C_{p}$ is the average thermal capacity for the fuel cell $\mathrm{CV}(\mathrm{J} /(\mathrm{kg} \cdot \mathrm{K})), \mathrm{Q}$ is the specific heat flow entering or leaving the calculated $\mathrm{CV}(\mathrm{J} / \mathrm{s})$.

The convective mass energy flow $Q_{m}$ is due to the temperature differences for the gas species entering and leaving the current $\mathrm{CV}$. The equation of the $Q_{m}$ can be expressed as:

$Q_{m}=\sum_{\text {species }} q_{g a s} M_{g a s} C_{g a s, s p}\left(T_{a m b}-T_{C V}\right)$

where $C_{\text {gas,sp }}$ is the thermal capacity for certain fuel gas species (J/ $(\mathrm{kg} \cdot \mathrm{K})), T_{a m b}$ is the temperature for the ambient CV $(\mathrm{K})$.

The forced convection $Q_{f c}$ happens at the interface between the anode channel and the anode electrode surface. The heat exchange can be described though the Newton cooling law as:

$Q_{f c}=h_{f c} S_{C V}\left(T_{a m b}-T_{C V}\right)$

where $h_{f c}$ is the forced convection coefficient $\left(\mathrm{W} /\left(\mathrm{m}^{2} \cdot \mathrm{K}\right)\right), S_{C V}$ is the section area of the $\mathrm{CV}$ in heat transfer direction $\left(\mathrm{m}^{2}\right)$.

The forced convection coefficient can be expressed as:

$h_{f c}=N u \cdot \lambda_{\text {gas }} / D_{c h}$

where $N u$ is the Nusselt number of gas in the channel, $\lambda_{\text {gas }}$ is the mixedgas average thermal conductivity $(\mathrm{W} /(\mathrm{m} \cdot \mathrm{K}))$ and $D_{c h}$ is the channel equivalent diameter $(\mathrm{m})$. The Nusselt number can be given as:

$N u=1.86 \cdot\left(\frac{C_{g a s} \cdot \rho_{g a s} \cdot L_{c h} \cdot u_{g a s}}{\lambda_{\text {gas }}}\right)^{1 / 3} \cdot\left(\frac{D_{c h}}{L_{c h}}\right)^{1 / 3}$

where $L_{c h}$ is the length of the channel (m), $u_{\text {gas }}$ is the mixed-gas velocity in the channel $(\mathrm{m} / \mathrm{s})$.

The conduction heat flow $Q_{c d}$ is generated between the different solid phase CVs. The equation can be described as:

$Q_{c d}=\sum \frac{K_{C V} S_{C V}}{\delta_{C V}}\left(T_{a m b}-T_{C V}\right)$

where $K_{C V}$ is the thermal conductivity for the $\mathrm{CV}(\mathrm{W} /(\mathrm{m} \cdot \mathrm{K})), \delta_{C V}$ is the thickness for the $\mathrm{CV}(\mathrm{m})$.

The expression of the natural convection and radiation heat flow $Q_{\text {nar }}$ is similar to that of the forced convection as:

$Q_{f c}=h_{n a r} S_{C V, e x}\left(T_{a m b}-T_{C V}\right)$

where $h_{\text {nar }}$ is the combined natural-convection and radiation heattransfer coefficients $\left(\mathrm{W} /\left(\mathrm{m}^{2} \cdot \mathrm{K}\right)\right), S_{C V \text {,ex }}$ is the external surface area of calculated $\mathrm{CV}\left(\mathrm{m}^{2}\right)$.

The internal PEMFC heat sources $Q_{\text {int }}$ covers the heat generations due to activation loss, resistance loss and irreversible electrochemical loss. It can be expressed as:

$Q_{\text {int }}=i\left(V_{\text {act }}+V_{\text {ohm }}-\frac{T_{\text {cata }} S^{0}}{2 F}\right)$

where $S^{0}=-163.185$ is the entropy change during the electrochemical reaction $(\mathrm{J} /(\mathrm{mol} \cdot \mathrm{K})), T_{\text {cata }}$ is the temperature of the catalyst $(\mathrm{K})$.

\subsection{Modeling parameters sensitivity analysis}

The sensitivity study for the semi-empirical parameters in a fuel cell model represents an important step during the model development. Such a study indicates the most and the least influencing parameter in a given set of modeling equations. Thus, it gives useful information for the choice of modeling assumptions and leads to a better understanding of the interactions between physical equations [35]. The uncertainty analysis of the fuel cell modeling parameters in the above-mentioned works can also help to improve the model performance during the full operating current range. In order to strengthen the model presented above, multi-parametric sensitivity analyze (MPSA) method is used to analyze the modeling parameters sensitivity. The major steps for MSPA can be expressed as [34]:

1. Select the parameters to be analyzed.

2. Set the numeric variation ranges of the parameters.

3. Generate a series of 500 random numbers for the parameter within the variation range.

4. Run the PEMFC model with the generated parameters, and calculate the corresponding objective function values for different operating conditions

5. Evaluate the relative sensitivity criteria at different fuel cell operating conditions of each parameter.

6. Evaluate the overall sensitivity criterion of each parameter.

Specifically, since one of the most important model output parameters for PEMFC is the cell output voltage, the activation overpotential and ohmic potential should be analyzed. The electrode catalyst area $A_{e l}$ is related to both $V_{\text {act }}$ and $V_{\text {ohm }}$, which can refer to (3) and (4), respectively. Thus, the electrode catalyst area can be selected as a target parameter. Moreover, the symmetry factors $\alpha$ and $\beta$ are all related to the activation overpotential, and thus they should also be selected as the target parameters. It should be noticed that the exchange current density $j_{0}$ in (3) can be expressed by the empirical equation shown as:

$j_{0}=\gamma_{c} \cdot P_{\mathrm{O}_{2}}^{\beta_{c}} \cdot e^{-\frac{E_{c}}{R T}\left(1-\frac{T}{298.15}\right)}$

where $E_{c}$ is the oxygen activation energy at electrode platinum interface, $\gamma_{c}$ and $\beta_{c}$ are the parameters that used to be identified through the fuel cell experimental tests, which can also be selected for the sensitivity analysis.

Moreover, the fuel gas pressure at the triple phase boundary can influence the reaction directly. During the mass transportation of the fuel gas, the Stefan-Maxwell equation is usually deployed to describe the diffusions. The pressure drop form diffusion layer to catalyst layer can implicitly reflect the transport losses, which is also known as concentration overpotential. However, the pressure drop is related to the effective gas diffusion coefficients, which can be expressed as:

$D_{\text {eff }, x}=D_{x, \mathrm{H}_{2} \mathrm{O}} \cdot \varepsilon^{\tau}$

where $D_{\mathrm{H}_{2}, \mathrm{H}_{2} \mathrm{O}}$ and $D_{\mathrm{O}_{2}, \mathrm{H}_{2} \mathrm{O}}$ are the binary gas diffusion coefficient for the hydrogen and oxygen, $\varepsilon$ is the porosity of the electrode and $\tau$ is the tortuosity of the electrode.

Thus, for the parameter sensitivity analysis, $D_{\mathrm{H}_{2}, \mathrm{H}_{2} \mathrm{O}}, D_{\mathrm{O}_{2}, \mathrm{H}_{2} \mathrm{O}}, \varepsilon$ and $\tau$ can all be selected. By applying the MSPA method, the sensitivity of the parameters is shown in the following table. For more details related to the modeling parameters analysis, please refer to [36-38].

\section{Power converter and dynamic load modeling}

$\mathrm{Z}$ source inverter can produce an output voltage greater than the AC input voltage, and it couples the converter main circuit as the power source for the load [24]. The simple architecture of the Z source inverter makes it suitable for the FCEV applications. In this section, the $\mathrm{Z}$ source inverter model will be built.

\subsection{Z Source inverter modeling}

As shown in Fig. 2, the Z-source network is a combination of two inductors $\left(L_{1}, L_{2}\right)$ and two capacitors $\left(C_{1}, C_{2}\right)$. The Z-source network provides a second-order filter, which is more effective to suppress voltage and current ripples when compared with the traditional 


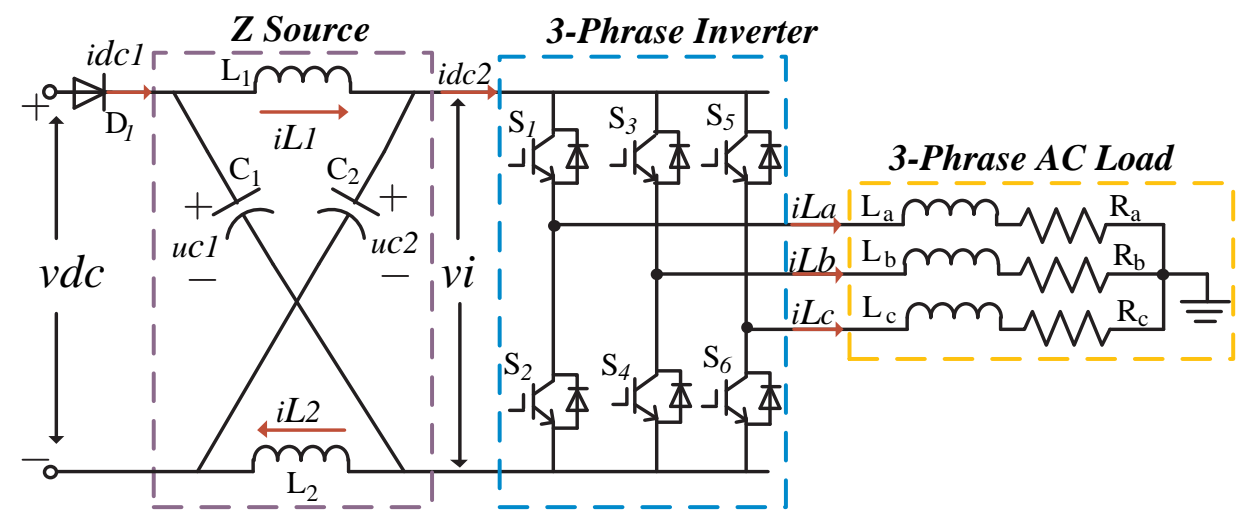

Fig. 2. Z Source inverter topology.

inverters [25-26]. Specifically, the inverter can operate under both non-shoot-through states and shoot-through states, which should be discussed separately.

First, we can focus on the $\mathrm{Z}$ source circuit, which is signified for the corresponding left part in Fig. 2. By supposing the inverter operating under shoot-through states, the inverter bridge is then equal to a short circuit shown in Fig. 3(a) as follows:

Assuming that the current $i_{L 1}$ and $i_{L 2}$ flowing through $L_{1}$ and $L_{2}$, respectively, and the capacitors voltage across $C_{1}$ and $C_{2}$ are $u_{c 1}$ and $u_{c 2}$, respectively. With the input voltage $v d c$ and circuit output voltage $v i$, the mathematic model for the circuit can be expressed as the following state-space equations:

$$
\left\{\begin{array}{c}
\mathrm{vdc}=\mathrm{uc} 1+\mathrm{uc} 2 \\
\mathrm{uc} 1=\mathrm{L}_{1} \frac{\mathrm{di}_{\mathrm{L} 1}}{\mathrm{dt}} \\
\mathrm{uc2}=\mathrm{L}_{2} \frac{\mathrm{di}_{\mathrm{L} 2}}{\mathrm{dt}} \\
\mathrm{C}_{1} \frac{\mathrm{du}_{\mathrm{c} 1}}{\mathrm{dt}}=\mathrm{i}_{\mathrm{dc} 2}-\mathrm{i}_{\mathrm{L} 1} \\
\mathrm{C}_{2} \frac{\mathrm{du}_{\mathrm{c} 2}}{\mathrm{dt}}=\mathrm{i}_{\mathrm{dc} 2}-\mathrm{i}_{\mathrm{L} 2} \\
\mathrm{v}_{\mathrm{i}}=0 \\
\mathrm{idc1}=0
\end{array}\right.
$$

Then, considering that the inverter is operating under the nonshoot-through states. During the switching cycle, the equivalent circuit can be used to describe this operating mode, which is shown in Fig. 3(b). It can be seen from the equivalent circuit that the output part is operated under the open circuit for vi, thus we can obtain the following (25). However, when the diodes $D_{1}$ are shut down, another updated state can be obtained as (26).

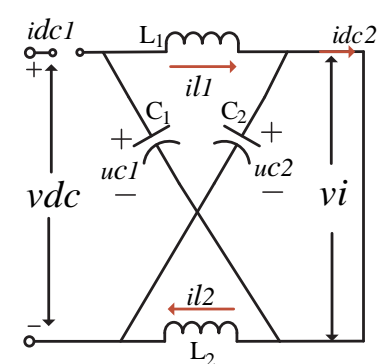

(a)

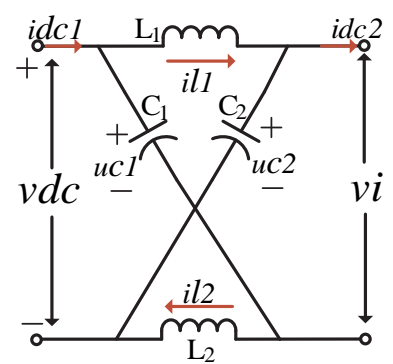

(b)
Fig. 3. Z source equivalent circuit.

$$
\begin{aligned}
& \left\{\begin{array}{c}
\mathrm{L}_{1} \frac{\mathrm{di}_{\mathrm{L} 1}}{\mathrm{dt}}=\mathrm{vdc}-\mathrm{uc} 2 \\
\mathrm{~L}_{2} \frac{\mathrm{di}_{\mathrm{L} 2}}{\mathrm{dt}}=\mathrm{vdc}-\mathrm{uc} 1 \\
\mathrm{C}_{1} \frac{\mathrm{du}_{\mathrm{c} 1}}{\mathrm{dt}}=\mathrm{i}_{\mathrm{dc} 2}+\mathrm{i}_{\mathrm{L} 2} \\
\mathrm{C}_{2} \frac{\mathrm{du}_{\mathrm{c} 2}}{\mathrm{dt}}=\mathrm{i}_{\mathrm{L} 1}-\mathrm{i}_{\mathrm{dc} 2} \\
\mathrm{v}_{\mathrm{i}}=\mathrm{uc} 1-\mathrm{L}_{1} \frac{\mathrm{di} 1}{\mathrm{dt}} \\
\mathrm{idc} 1=\mathrm{i}_{\mathrm{L} 1}-\mathrm{i}_{\mathrm{dc} 2}+\mathrm{i}_{\mathrm{L} 2}
\end{array}\right. \\
& \left\{\begin{array}{c}
i_{L 1}=0.5 \mathrm{i}_{\mathrm{dc} 2} \\
i_{L 2}=0.5 \mathrm{i}_{\mathrm{dc} 2} \\
\mathrm{C}_{1} \frac{\mathrm{du}_{\mathrm{c} 1}}{\mathrm{dt}}=-\mathrm{i}_{\mathrm{L} 1} \\
\mathrm{C}_{2} \frac{\mathrm{du}_{\mathrm{c} 2}}{\mathrm{dt}}=-\mathrm{i}_{21} \\
\mathrm{v}_{\mathrm{i}}=\mathrm{uc} 1-\mathrm{L}_{1} \frac{\mathrm{di}_{\mathrm{L} 1}}{\mathrm{dt}} \\
\mathrm{idc} 1=0
\end{array}\right.
\end{aligned}
$$

The IGBT devices in the three-phase inverter are all considered as ideal switches. The diode has zero impedance when it is on and an infinite impedance when it is off. The value of switch function $S$ can be defined with the value of phrase current Ic and the driving signal Vg.

The two-level inverter topology is shown in Fig. 4. With previous mentioned switch function $S$, we can define $S_{i}(i=1,3,5)=1$ when the IGBT $\mathrm{S}_{\mathrm{i}}(\mathrm{i}=1,3,5)$ or parallel Diode $\mathrm{D}_{\mathrm{i}}(\mathrm{i}=1,3,5)$ are turned on, otherwise $S_{i}(i=1,3,5)=0$. We can then get the following equations for calculating the state of inverter as follows:

$$
\left\{\begin{array}{c}
U_{a o}=\frac{1}{3} v_{i}\left(2 S_{1}-S_{2}-S_{3}\right) \\
U_{b o}=\frac{1}{3} v_{i}\left(2 S_{2}-S_{1}-S_{3}\right) \\
U_{c o}=\frac{1}{3} v_{i}\left(2 S_{3}-S_{1}-S_{2}\right) \\
i_{d c 2}=S_{1} i_{a}+S_{3} i_{b}+S_{5} i_{c}
\end{array}\right.
$$

Compared with traditional inverter which can avoid the bridge

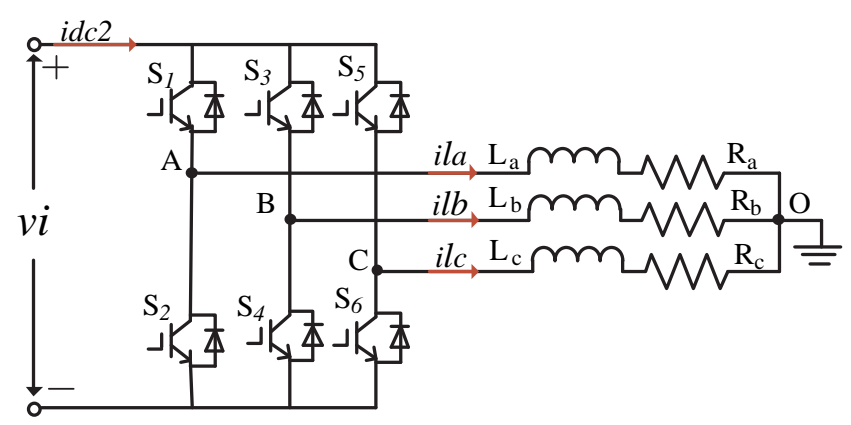

Fig. 4. Inverter modeling. 


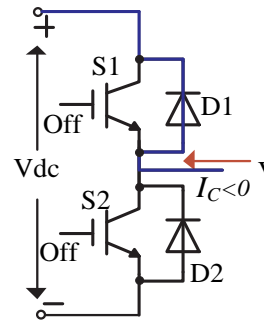

(a)

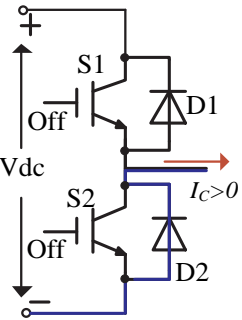

(b)

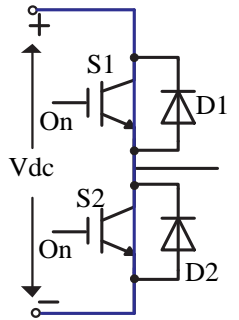

(c) (a) (b) Current path during dead-time (c) Shoot-through performance

Fig. 5. Switch status during dead-time and shoot-through. (a) and (b) Current path during dead-time and (c) Shoot-through performance.

shoot-through but introduce dead-time (as shown in Fig. 5(a) and (b)), the bridge shoot-through (as shown in Fig. 5(c)) can play an important role during the control cycle. To take into consideration the effect of shoot-through, the definition of the switch function can be expressed as follows:

$\left\{\begin{array}{l}U_{a o}=0 \\ U_{b o}=0 \\ U_{c o}=0\end{array}\right.$

\subsection{Electric machine modeling}

The AC load used in this application is a squirrel-cage machine. The motor model is a generalized model based on the stator stationary reference frame, which can provide a set of predetermined electrical and mechanical parameters including various asynchronous machine ratings of power (HP), phase-to-phase voltage (V), frequency (Hz) and rated speed $(\mathrm{rpm})[27,28]$. The input variable $\mathrm{u}_{\mathrm{s} \alpha}$ and $\mathrm{u}_{\mathrm{s} \beta}$ are the voltage $\mathrm{U}_{\mathrm{il}}, \mathrm{U}_{\mathrm{jl}}, \mathrm{U}_{\mathrm{kl}}$ after Clark conversion. The load model can be described as:

$\left[\begin{array}{c}\frac{d \varphi_{r \alpha}}{d t} \\ \frac{d \varphi_{r \beta}}{d t} \\ \frac{d i_{s \alpha}}{d t} \\ \frac{d i_{s \beta}}{d t}\end{array}\right]=A \cdot\left[\begin{array}{c}\varphi_{r \alpha} \\ \varphi_{r \beta} \\ i_{s \alpha} \\ i_{s \beta}\end{array}\right]+B \cdot\left[\begin{array}{c}u_{s \alpha} \\ u_{s \beta} \\ 0 \\ 0\end{array}\right]$

where

$A=\left[\begin{array}{cccc}-\frac{1}{\mathrm{~T}_{\mathrm{r}}} & -\omega & \frac{\mathrm{L}_{\mathrm{m}}}{\mathrm{T}_{\mathrm{r}}} & 0 \\ \omega & -\frac{1}{\mathrm{~T}_{\mathrm{r}}} & 0 & \frac{\mathrm{L}_{\mathrm{m}}}{\mathrm{T}_{\mathrm{r}}} \\ \frac{\mathrm{L}_{\mathrm{m}}}{\sigma \mathrm{L}_{\mathrm{S}} \mathrm{L}_{\mathrm{r}} \mathrm{T}_{\mathrm{r}}} & \frac{\mathrm{L}_{\mathrm{m}} \omega}{\sigma \mathrm{L}_{\mathrm{S}} \mathrm{L}_{\mathrm{r}} \mathrm{T}_{\mathrm{r}}} & -\frac{\mathrm{R}_{\mathrm{s}} \mathrm{L}_{\mathrm{r}}^{2}+\mathrm{R}_{\mathrm{r}} \mathrm{L}_{\mathrm{m}}^{2}}{\sigma \mathrm{L}_{\mathrm{s}} \mathrm{L}_{\mathrm{r}}^{2}} & 0 \\ \frac{-\mathrm{L}_{\mathrm{m}} \omega}{\sigma \mathrm{L}_{\mathrm{S}} \mathrm{L}_{\mathrm{r}} \mathrm{T}_{\mathrm{r}}} & \frac{\mathrm{L}_{\mathrm{m}}}{\sigma \mathrm{L}_{\mathrm{s}} \mathrm{L}_{\mathrm{r}} \mathrm{T}_{\mathrm{r}}} & 0 & -\frac{\mathrm{R}_{\mathrm{S}} \mathrm{L}_{\mathrm{r}}+\mathrm{R}_{\mathrm{r}} \mathrm{L}_{\mathrm{m}}^{2}}{\sigma \mathrm{L}_{\mathrm{S}} \mathrm{L}_{\mathrm{r}}^{2}}\end{array}\right] ;$

$B=\left[\begin{array}{cccc}0 & 0 & 0 & 0 \\ 0 & 0 & 0 & 0 \\ 0 & 0 & \frac{1}{\sigma L_{S}} & 0 \\ 0 & 0 & 0 & \frac{1}{\sigma L_{S}}\end{array}\right] ; \quad \sigma=1-\frac{L_{m}^{2}}{L_{S} L_{r}}, \quad T_{r}=\frac{L_{r}}{R_{r}}$

where $\mathrm{L}_{\mathrm{m}}$ is the mutual inductance $(\mathrm{mH}) ; \mathrm{L}_{\mathrm{ls}}, \mathrm{L}_{\mathrm{lr}}$ are the stator and rotor inductances (mH); Rs, Rr are the stator and rotor resistances $(\Omega) ; \mathrm{n}_{\mathrm{p}}$ is the number of poles and $J$ is the total rotor inertia $\left(\mathrm{kg} \cdot \mathrm{m}^{2}\right) \cdot \omega_{\mathrm{r}}$ is the electrical rotor speed ( $\mathrm{rad} / \mathrm{s})$, which can be calculated by the following equation: $\left\{\begin{array}{c}\frac{d \omega}{d t}=T e-\frac{n_{p}}{J} T_{M} \\ T e=\frac{n_{p}^{2} L_{m}}{J L_{r}}\left(i_{s \beta} \varphi_{r \alpha}-i_{s \alpha} \varphi_{r \beta}\right)\end{array}\right.$

where torque $\mathrm{T}_{\mathrm{M}}$ indicates a torque input $(\mathrm{N} \cdot \mathrm{m})$.

The machine speed is determined by the machine Inertia $\mathrm{J}$, the difference between the applied mechanical torque $T_{M}$ and the internal electromagnetic torque $\mathrm{Te}(\mathrm{N} \cdot \mathrm{m})$. When the speed is positive, a positive torque signal indicates the motor mode and a negative signal indicates the generator mode. However, we can also select speed $w$ to specify a speed input. Then, the machine speed is imposed and the mechanical part of the model (Inertia $\mathrm{J}$ ) will be ignored.

\section{Solving algorithms for hybrid system}

In order to efficiently solving the developed hybrid system model, appropriate algorithms should be applied. In this section, the fuel cell and FPGA solver will be discussed. Together with CPU-FPGA co-simulation framework, the overall hybrid systems model and solving algorithms are demonstrated.

\subsection{Fuel cell stack solving algorithm}

For embedded applications like real-time simulation, the control oriented multi-physical model need to be solved in real-time, and the algorithm design is of great importance to the model. In our previous mentioned fuel cell model, the Butler-Volmar equation is used instead of Tafel approximation for activation overpotential calculation. Thus, a suitable solver should be applied to the fuel cell.

\subsubsection{Model boundary condition}

In order to solve the differential equations among different domains (electrochemical, fluidic and thermal), it is necessary to indicate the boundary conditions for each calculated cell in the stack. The fuel cell stack power $V_{\text {stack }}$ and the total current $i_{\text {stack }}$ can be figured out as:

$i_{\text {stack }}=i_{\text {cell }}$ for $i=1$ to $\mathrm{N}$

$$
V_{\text {stack }}=\sum_{i=1}^{N} V_{\text {cell, }, i}
$$

where $\mathrm{N}$ is the total number for the cells in the stack, $V_{\text {cell }}$ and $i_{\text {cell }}$ are the voltage and current for the individual cell, respectively.

\subsubsection{PEMFC solver configuration}

Due to different physical conditions like the fuel cell operating temperature and the reaction gas pressure, an iterative algorithm should be used in order to efficiently determine the physical quantities inside the fuel cell. The proposed solver can be easily applied to embedded applications like real-time simulation. As described in the flowchart shown in Fig. 6, the fuel cell model will first execute the mass model with the input parameters. Then the thermal phenomenon can be figured out with the results from the mass distribution. At last, the electrochemical domain can be applied to calculate the voltage

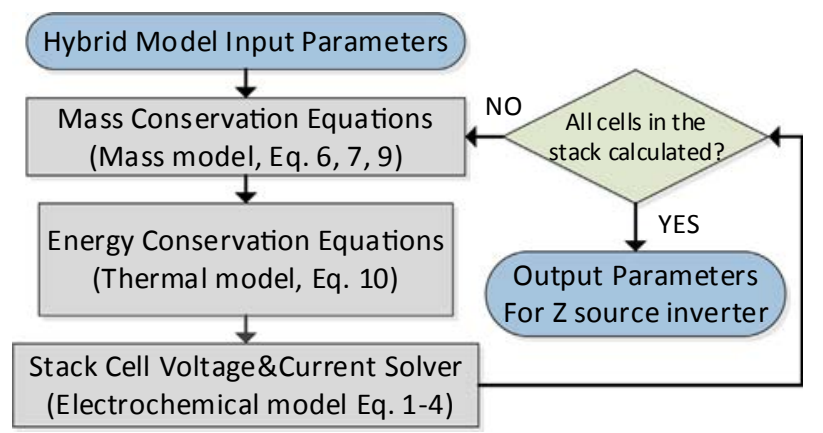

Fig. 6. Fuel cell solving algorithm. 


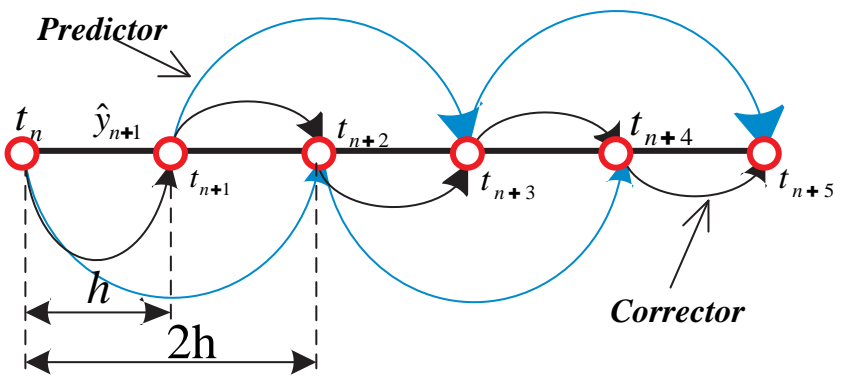

Fig. 7. Parallel predictor and corrector solver algorithm.

distribution. Before the final output, the model will check if all cells in the stack are calculated.

\subsection{FPGA solver}

The methods for modeling power electronic system can be regarded as a class of first-order ordinary equation with the formation of state space equations. An explicit method is used to obtain the initial approximation to the solution $\mathrm{y}\left(\mathrm{t}_{\mathrm{n}}\right)$ in the current time point $\mathrm{t}_{\mathrm{n}}$. Then, an implicit algorithm is applied with a fixed number of iterations. Taking the explicit and implicit Euler method as an example, the modified parallel process can be written in (32) as [29]:

P-step: $\hat{y}_{n+2}=y_{n}+2 \cdot h \cdot f\left(t_{n}, y_{n}\right)$

C-step: $\mathrm{y}_{n+1}=y_{n}+\frac{h}{2} \cdot\left(f\left(t_{n}, \hat{y}_{n+1}\right)+f\left(t_{n}, y_{n}\right)\right)$

As shown in Fig. 7, the method calculates the predictor value $\hat{y}_{n+2}$ at time point $t_{n}$ within the process solving $y_{n+1}$. In the next time step $t_{n+1}$, when we estimate the value of $y_{n+2}$, the value of $\hat{y}_{n+2}$ is already known from last step calculation. As a result, $\hat{\mathrm{y}}_{\mathrm{n}+2}$ and $\mathrm{y}_{\mathrm{n}+1}$ can be obtained at the same time. It should be noticed that when compared to the corresponding formulas for the sequential process involving the explicit and implicit Euler algorithm, there is a slightly difference in the truncation error, whereas the speed ratio can still reach 2 .

Fig. 8(a) is the Predictor and Corrector Structure. Inside the framework, both C-step and P-step have a math calculation unit, which consists of fixed-point multiplications and Sub/Add operation. After the calculation is done, results are stored in registers. In order to calculate

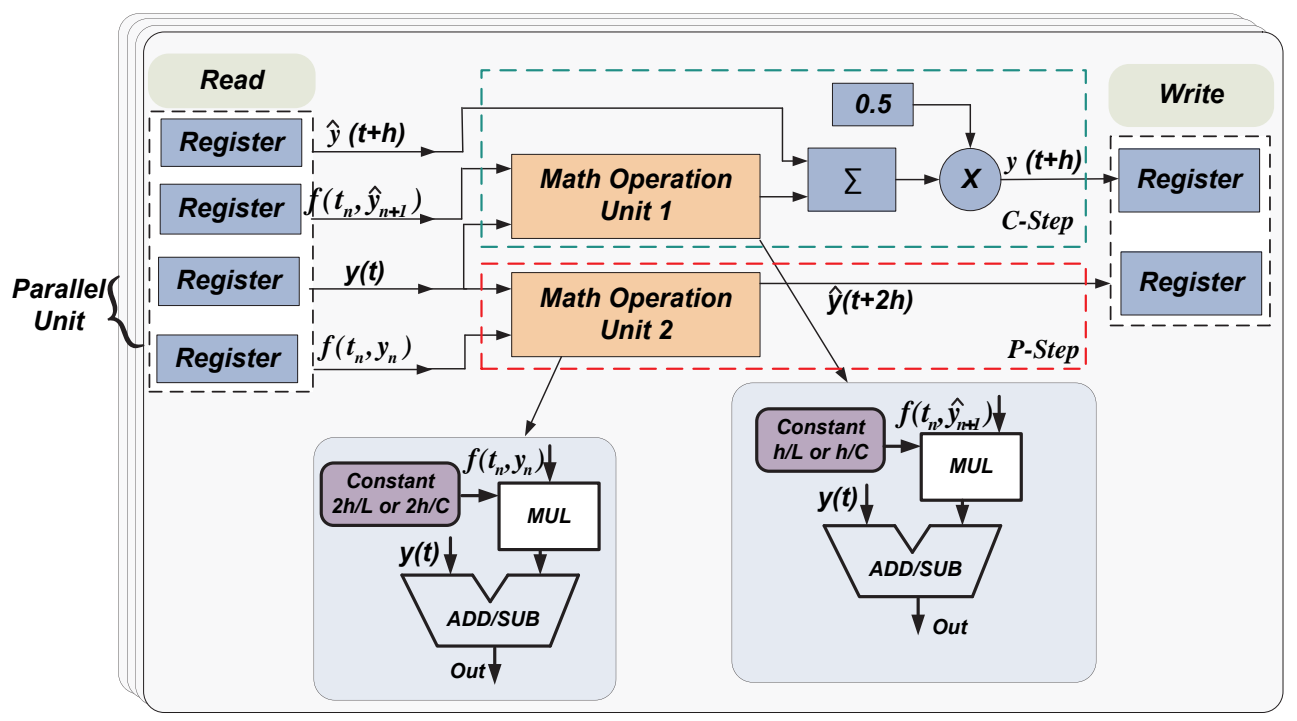

(a) Parallel ODE solver structure in FPGA

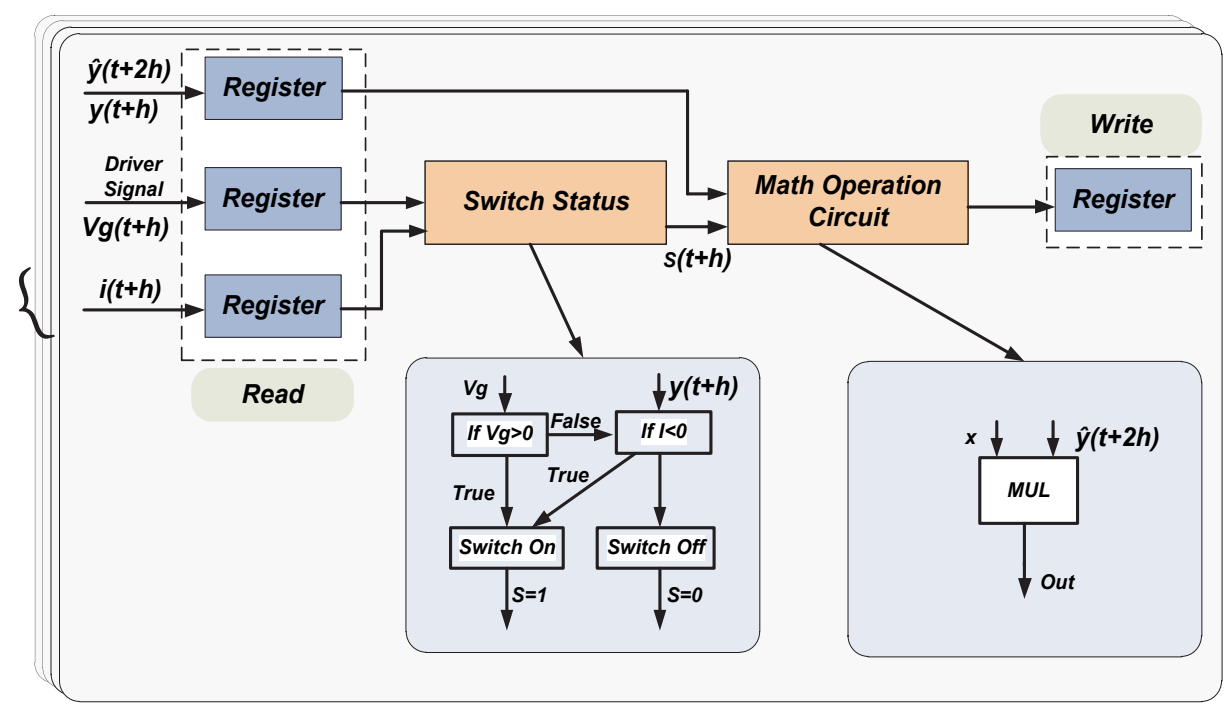

(b) Switch status judgment

Fig. 8. Parallel ODE solver structure in FPGA. 


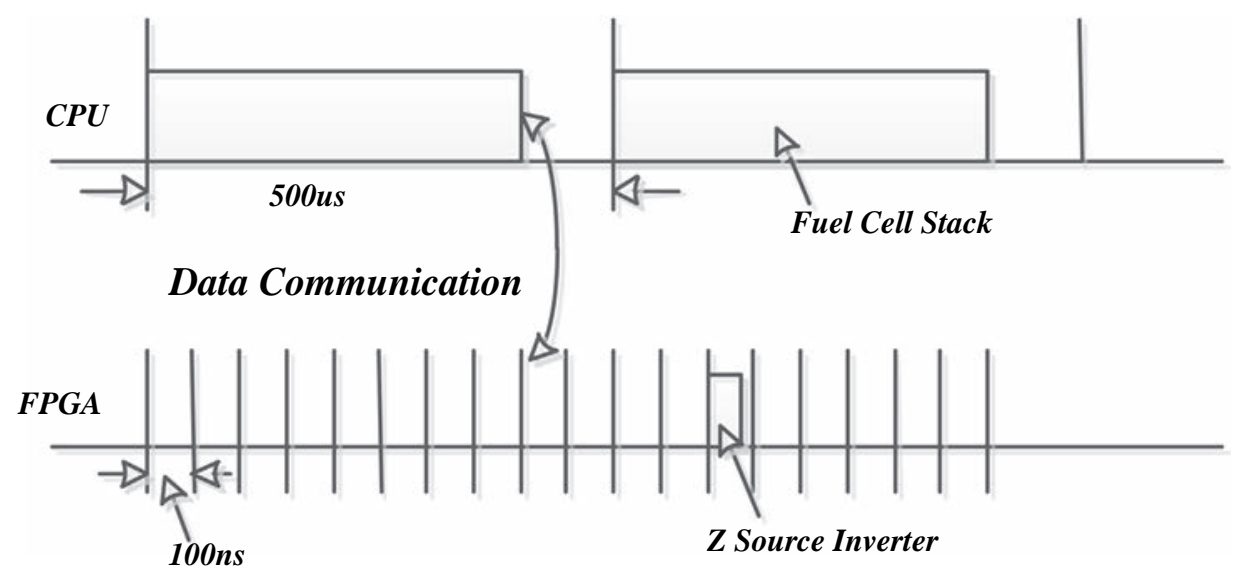

Fig. 9. Time sequence of simulation in HIL system.

Table 1

Fuel cell model parameter sensitivity analysis.

\begin{tabular}{llll}
\hline Symbol & Parameter & Test range & Sensitivity \\
\hline$\gamma_{c}$ & $\begin{array}{l}\text { Exponential parameter of } \\
\text { exchange current density }\end{array}$ & $\pm 10 \%$ & Insensitive \\
$\beta_{c}$ & $\begin{array}{l}\text { Scale factor of exchange current } \\
\text { density }\end{array}$ & $\pm 10 \%$ & $\begin{array}{l}\text { Sensitive in whole } \\
\text { current range }\end{array}$ \\
$A_{e l}$ & Electrode catalyst area & $\pm 10 \%$ & $\begin{array}{l}\text { Sensitive in high } \\
\text { current range }\end{array}$ \\
$\alpha$ & Symmetry factor & $\pm 10 \%$ & $\begin{array}{l}\text { The most sensitive } \\
\text { Insensitive }\end{array}$ \\
$D_{\mathrm{H}_{2}, \mathrm{H}_{2} \mathrm{O}}$ & $\begin{array}{l}\text { Gas diffusion coefficient } \mathrm{H}_{2} \text { and } \\
\text { water }\end{array}$ & $\pm 10 \%$ & $\begin{array}{l}\text { Sensitive in high } \\
\text { current range }\end{array}$ \\
$D_{\mathrm{O}_{2}, \mathrm{H}_{2} \mathrm{O}}$ & $\begin{array}{l}\text { Gas diffusion coefficient } \mathrm{O}_{2} \text { and } \\
\text { water }\end{array}$ & $\pm 10 \%$ & $\begin{array}{l}\text { Sensitive in high } \\
\text { current range }\end{array}$ \\
$\varepsilon$ & Porosity & $\pm 10 \%$ & $\begin{array}{l}\text { Sensitive in high } \\
\text { current range }\end{array}$ \\
$\tau$ & Tortuosity & $\pm 10 \%$ & \\
\hline
\end{tabular}

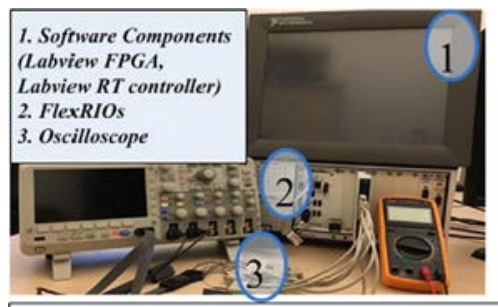

FlexRIOs (Flexible Reconfigurable IO) (a) NI 7975R FlexRIO FPGA Module (Kintex-7) (b) NI 5741 Adapter Module (200MHz)

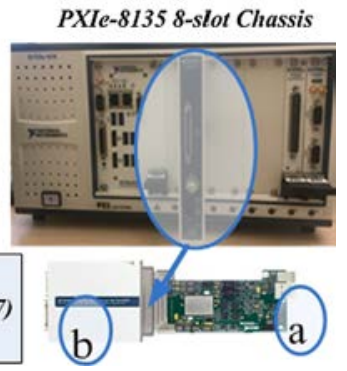

Fig. 10. NI PXIe-8135 platform setup.
Table 2

Hardware resource utilization for the case study.

\begin{tabular}{llll}
\hline Resources & Used & Total & Percentage \\
\hline Total Slices & 17,020 & 63,550 & $27.3 \%$ \\
Slice Registers & 42,375 & 508,400 & $8.3 \%$ \\
Slice LUTs & 45,081 & 254,200 & $17.7 \%$ \\
Block RAMs & 91 & 795 & $11.4 \%$ \\
DSP48s & 84 & 1540 & $5.5 \%$
\end{tabular}

the switch status, we need both the driver signal and the phrase current. The internal structure of switch status judgment is shown in Fig. 8(b).

\subsection{CPU-FPGA based co-simulation formulation}

In our proposed framework, the fuel cell can be executed in CPU with a larger time step of $500 \mu \mathrm{s}$, whereas the $\mathrm{Z}$ source converter can be computed within $100 \mathrm{~ns}$. Sub-system running at different simulation time steps cannot immediately exchange information within a limited error before the signal simulation rate decreases (down-sample) or increases (up-sample). The time sequence of these two parts can be figured out in Fig. 9.After that the fuel cell stack model computes the output voltage $V d c=V_{\text {cell }}$, the value will be transmitted from FPGA (sample time $\mathrm{Ta}=100 \mathrm{~ns}$ ) to $\mathrm{CPU}$ (sample time $\mathrm{Tb}=500 \mu \mathrm{s}$ ). Since the sample time $\mathrm{Tb} \gg \mathrm{Ta}$, the source $V d c$ and the motor speed $\mathrm{w}$ can be considered as constant values. However, the current $i d c 1$, which is transmitted from FPGA to CPU, may encounter the problem of downsampling. In order to reduce this affect, we can deploy the average value of idc1 in CPU as follows:

$\overline{i(t)}=\sum_{k=1}^{n}\left(\frac{1}{n} \dot{i}(k-1)\right)$

where $n=T b / T a$.

\section{Real-time simulation implementation and discussion}

In this section, the real-time simulation results of individual parts will be demonstrated through the proposed model in previous sections. Meanwhile, the simulation results of the hybrid system are also analyzed and discussed.

\subsection{PEMFC implementation in $C P U$}

Interaction between MATLAB and LabVIEW can be accomplished by generating a Phar Lap ETS Targets *.dll file which enables the two softwares to exchange data in real-time. This dynamic library is usually generated by NI Model interface toolkit (MIT) [30]. This program and related subprograms provide a way to create a LabVIEW user-friendly interface, which can efficiently improve the communication with the MATLAB/Simulink model. The model parameters can be manipulated and the output data can be viewed (see Table 1).

\section{2. $Z$ source inverter implementation in FPGA}

The hardware setup for the case studies is presented in Fig. 10. The FPGA is Kintex-7 XC7K410T FPGA [31] embedded in the NI PXIe7975R FlexRIO PXI Express FPGA module [32], which has a $400 \mathrm{Mb} / \mathrm{s}$ 


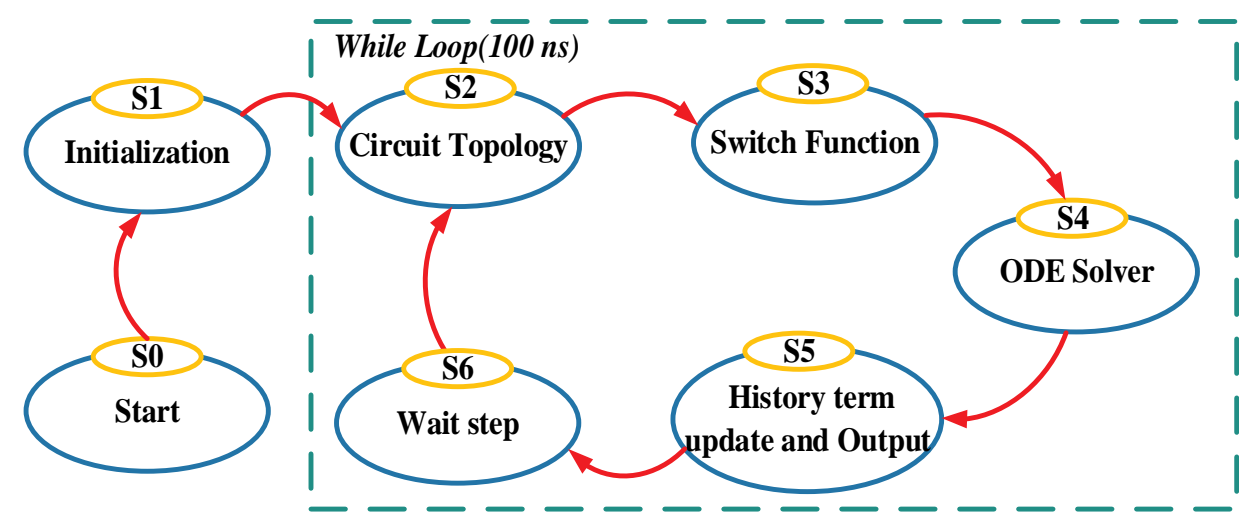

Fig. 11. Finite-state machine in real time simulation flow.

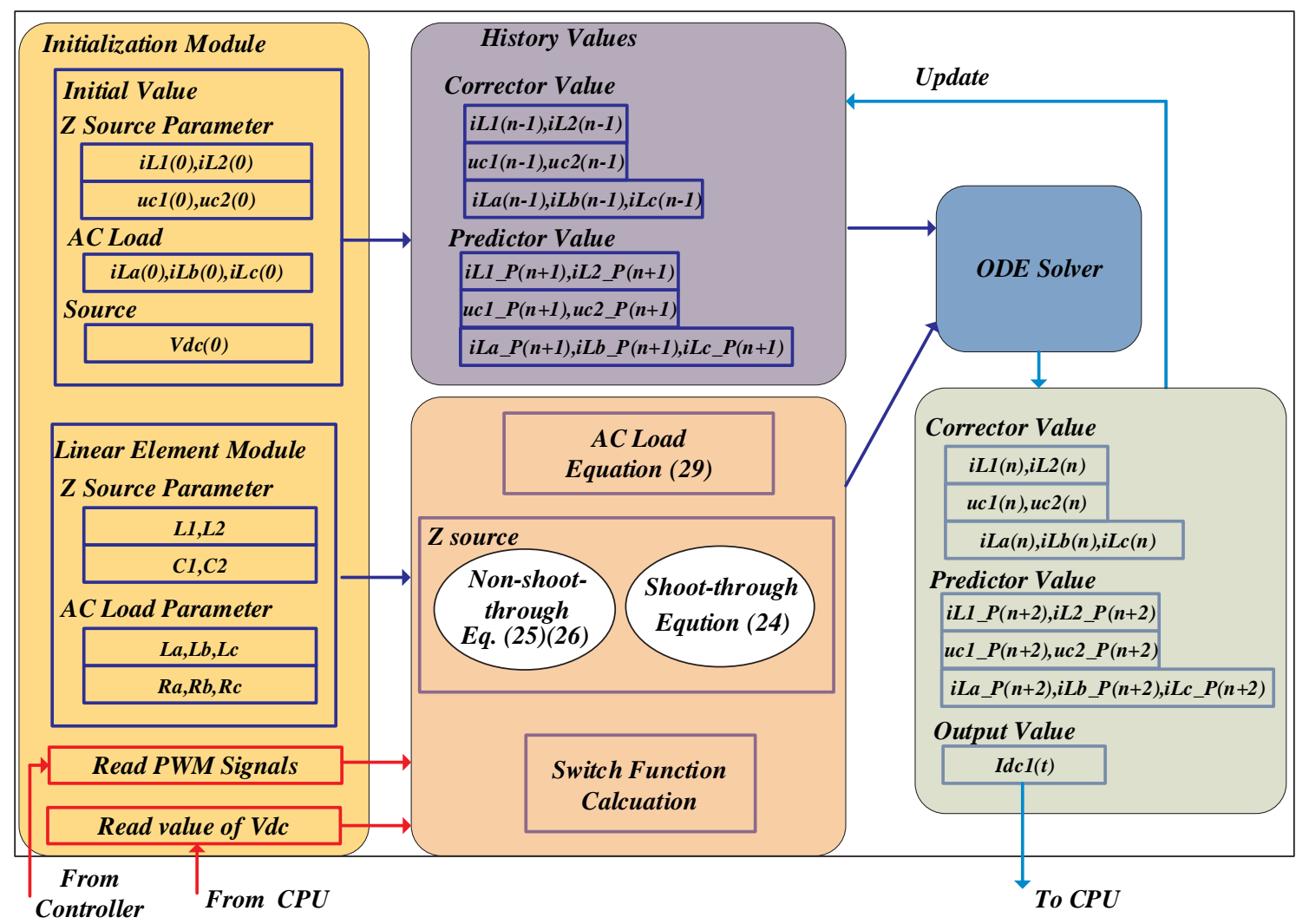

Fig 12. Hardware Implementation and data flow of real-time simulation.

Table 3

Simulation Parameter.

\begin{tabular}{ll}
\hline Resources & Value \\
\hline Inductance $L 1, L 2$ & $1.6 \mathrm{mH}$ \\
Capacitance $C 1, C 2$ & $1000 \mu \mathrm{F}$ \\
Stator inductance $R_{S}$ & $0.00347 \Omega$ \\
Rotor resistances $R_{r}$ & $0.005476 \Omega$ \\
Stator inductances leakage $L_{l s}$ & $0.01254 \mathrm{mH}$ \\
Rotor inductances leakage $L_{l r}$ & $0.01226 \mathrm{mH}$ \\
Mutual inductance $L_{m}$ & $0.3329 \mathrm{mH}$ \\
Rotor inertia: J & $0.0131 \mathrm{~N} \cdot \mathrm{m}$ \\
Poles: $n_{p}$ & 2 \\
\hline
\end{tabular}

single-ended configuration rate. It contains 508,400 Slice Registers, 63,550 Total Slices, 254,200 Slice LUTs, 795 Block RAMs and 1540 DSP48s. The FPGA board output analog signals via the NI 5741 Adapter Module. The Tektronix MSO 2048B oscilloscope is used to capture and store the analog signals form the Adapter Module. The hardware consumption in this case study is also presented in Table 2 .

Fig. 11 is the finite-state machine (FSM) used to control the overall simulation flow, which is shown in Fig. 12. As can be seen from Fig. 11, when the reset signal is detected, the state $S_{1}$ will begin with initial module, which is used to calculate the system constants. This state utilizes user-define circuit parameters to avoid repetitive calculations, and the initial value of the inductance current $\left(i_{L 1}(0), i_{L 2}(0)\right)$ and capacitance voltage $\left(v_{c 1}(0), v_{c 2}(0)\right)$ are defined and stored in register.

After the initialization process, the real-time simulator will enter into the while loop, which means the calculation is started. For the first step, state $S_{2}$ receives the control signal from controller and judges whether the inverter is in shoot-through statues. Once the $\mathrm{Z}$ source inverter is in shoot-through status, (24) will be deployed. Otherwise, the inverter equations will be presented by (25) and (26).

After the topology of the inverter is set, the FSM will enter the switch function calculation unit (the structure of which is shown in 


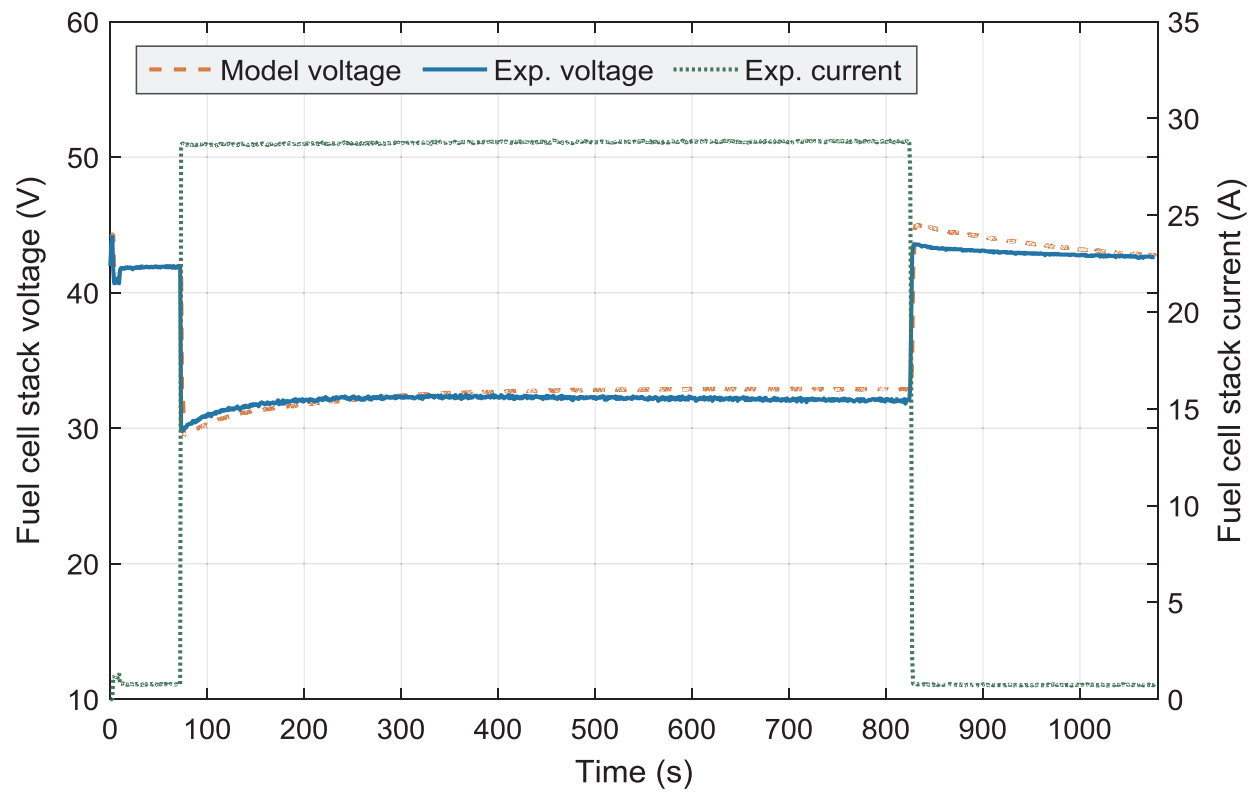

Fig. 13. Fuel cell static state operating under medium load.

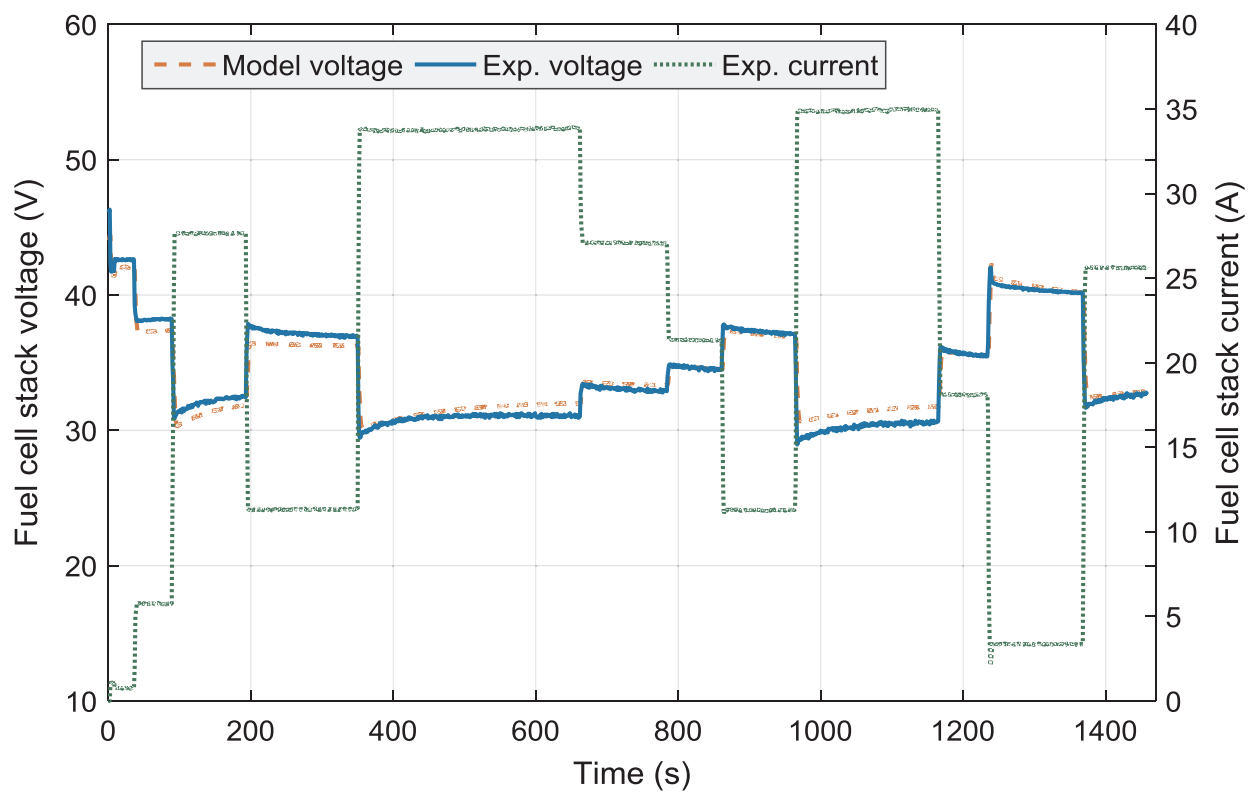

Fig. 14. Fuel cell dynamic operating under slow load variation.

Fig. 8(b)) with state $S_{3}$. As can be seen from Fig. 12, the value of the switch function will be obtained with the predictor current value $\left(i_{L a}{ }^{p}\left(t_{n+1}\right), i_{L b}^{p}\left(t_{n+1}\right), i_{L c}^{p}\left(t_{n+1}\right)\right)$ and control signal $\left(S_{i}(i=1 \cdots 6)\right)$ in this state.

Once $S_{3}$ is done, FSM begins state $S_{4}$ and utilizes ODE solver (the structure of which is shown in Fig. 8(a)) to solve the state-space equation. Meanwhile, the corresponding predictor calculation $\left(i_{L a b c}^{p}\left(t_{n+2}\right), i_{L}^{p}\left(t_{n+2}\right), v_{c}^{p}\left(t_{n+2}\right)\right)$ begins simultaneously as shown in Fig. 12. Since the time step is relative small $(100 \mathrm{~ns})$, the inter-switch event is not likely to happen.When the calculation is finished, the FSM will enter into state $S_{5}$. The state $S_{5}$ will receive the results from the calculation unit and update the register which stores the predictor value and corrector value from last time step. Then the state $S_{6}$ will wait the next calculation loop until 100 ns runs out.

\subsection{Real-time emulation results and discussion}

In this part, real-time simulation results have been performed and discussed in order to validate the above modeling and implementations. The simulation parameters are listed in Table 3.

Usually three working zones including activation region, ohmic region and mass transport region can be identified for the fuel cell operating. The first region is the activation voltage drop due to the slowness of the chemical reactions at electrode surfaces. The second region shows the resistive losses because of the internal resistance inside FEMFC. The third region depicts the mass transport losses as a result of the change in concentration of reactants.

In order to show the fuel cell model accuracy in a broad range of operating conditions, different operating conditions for the fuel cell model are discussed. Specifically, the fuel cell model under static state current operating is firstly validated by the experimentally measured results. As can be seen from the following Fig. 13, when a medium load 


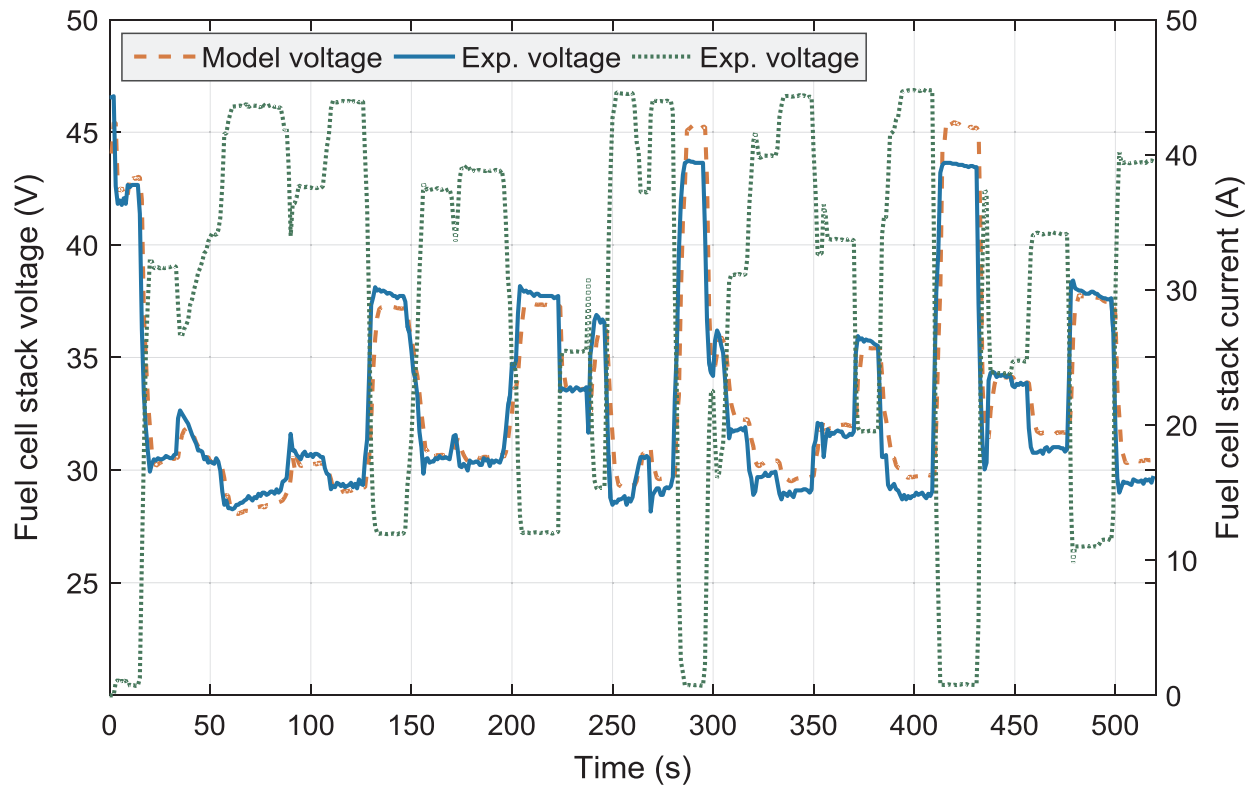

Fig. 15. Fuel cell dynamic operating under fast load variation.

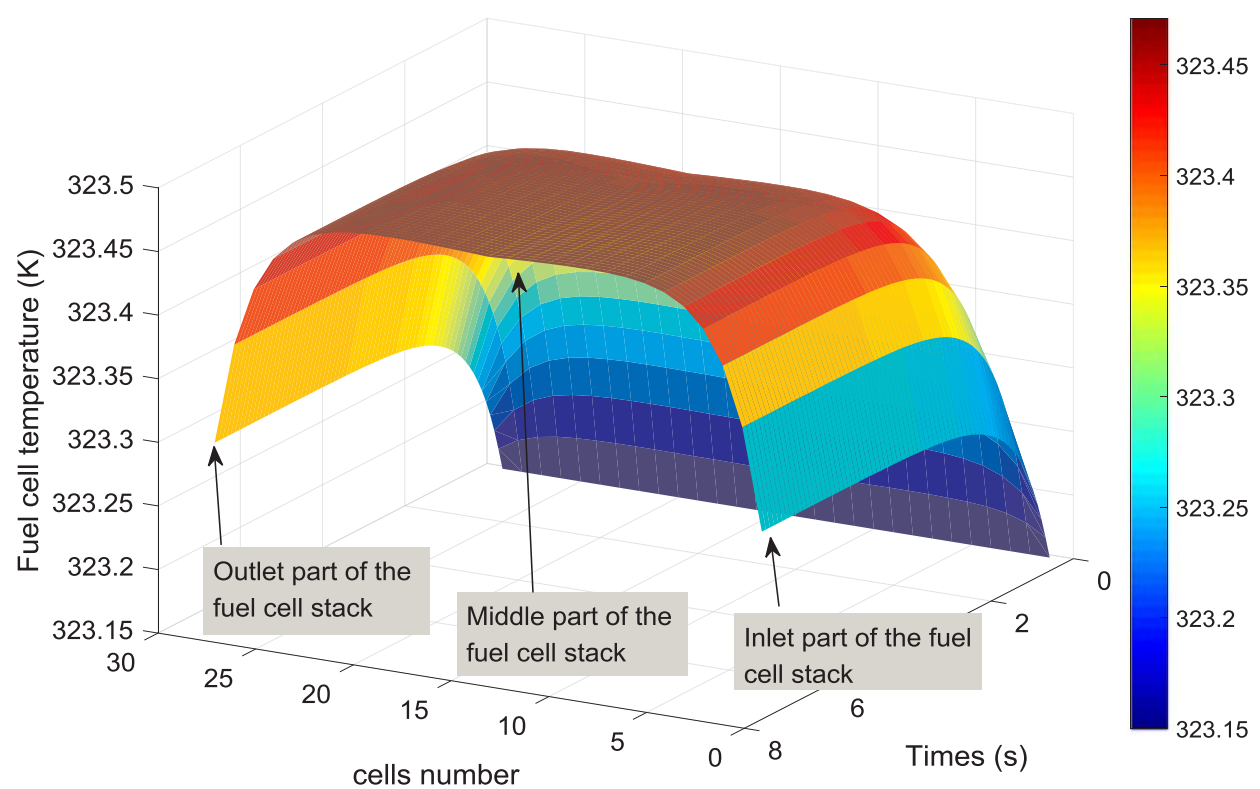

Fig. 16. Temperature distribution of the individual cells in the stack.

is applied to the fuel cell, the operating current is set to $28 \mathrm{~A}$. The predicted stack output voltage from the model can follow the experimentally measured one very well with the maximum relative error of $4.6 \%$.

Moreover, in order to verify the dynamic performance of the proposed fuel cell model, experimentally measured dynamic fuel cell output data are used. Fig. 14 demonstrates the fuel cell operating under a slow load variation. During the $1470 \mathrm{~s}$ operating time, the output voltage varies for 12 times. The modeling results indicate a great agreement compared with the experimental ones, with a maximum relative error of $3.2 \%$.

Furthermore, the fuel cell model performance under fast dynamic load variations is also tested. As can be seen from Fig. 15, the fuel cell load varies with a high frequency during the $600 \mathrm{~s}$ operating time. However, the model output voltage can still capture the variation rapidly in a very good agreement. The quick dynamic response of the model can guarantee that the output voltage follows the experimentally measured results with a maximum relative error of $4.5 \%$.

Fig. 16 describes the corresponding modeled fuel cell stack temperature distributions for individual cells after a step current input. It can be seen from the figure that the middle part of the fuel cell has the highest temperature, and the inlet part along with the outlet part commit the lowest one. Thus, during the fuel cell operating, the middle part of the stack will face more thermal forces than the other parts. The temperature distribution can also help to signify the fuel cell operating states.

To illustrate the achievable performance of the state space equation solver and modeling method of $\mathrm{Z}$ source inverter, we can then make comparison between proposed solver in FPGA and the variable step solver in MATLAB/Simulink. The power source is set to a $500 \mathrm{~Hz}$ triangle waveform ranging from $90 \mathrm{~V}$ to $95 \mathrm{~V}$. An open-loop PWM control strategy is used to ensure the error comes only from the proposed modeling method.

As can be seen from the Fig. 17, the voltage of $\mathrm{C} 1$ is boosted to about 

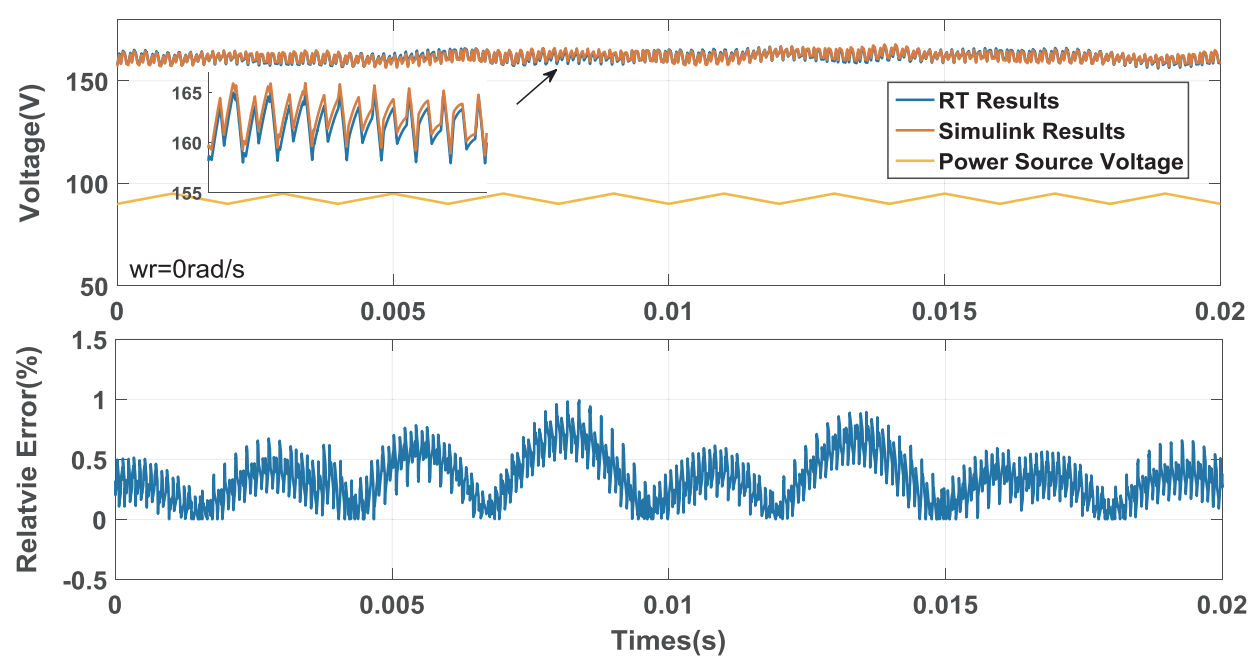

(a. $T_{0} / T=0.333$ and the motor speed is set to $0 \mathrm{rad} / \mathrm{s}$ )
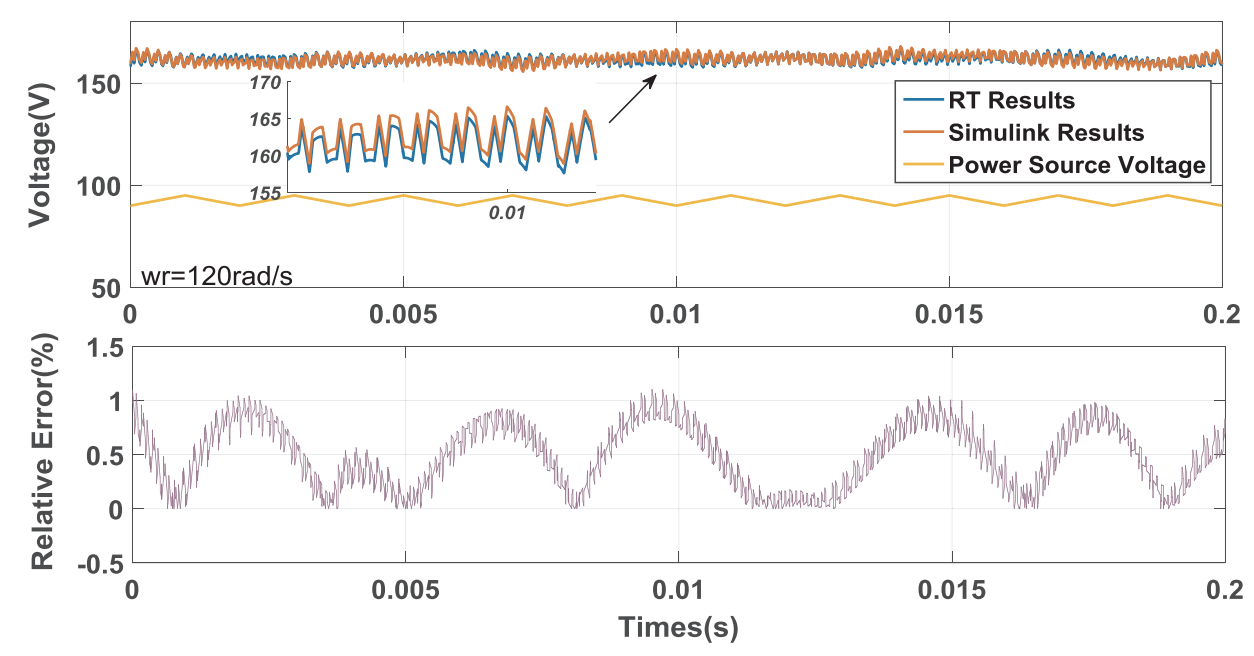

(b. $T_{0} / T=0.333$ and the motor speed is set to $120 \mathrm{rad} / \mathrm{s}$ )

Fig. 17. Real-time simulation results under shoot-through duty cycle.

$160 \mathrm{~V}$ regardless of the changing of motor speed. From the theoretical analysis in ZSI [24], we can come to the following calculation equation:

$\mathrm{Vc} 1=\mathrm{Vc} 2=\frac{1-T_{0} / T}{1-2 T_{0} / T}=92.5 * 1.833=170 \mathrm{~V}$

It can be seen from Fig. 17 that the above waveforms are consistent with the numerical analysis. The relative error is below $1 \%$. Thus, it can be concluded that the real-time simulation results have a high precision.

The current curve flow through inductance $\mathrm{L}_{1}$ can be seen in Fig. 18 . When the motor speed increases, the current will decrease. For most cases, the maximum relative error between the proposed solver and Simulink simulation results are below $3 \%$, which is acceptable.Fig. 19 is the current waveform of ila. The current values work as the output of motor. Since the PWM control frequency in the controller that is set to $50 \mathrm{~Hz}$, the cycling period is $0.02 \mathrm{~s}$. The dashed red line is the Simulink simulation results, whereas the blue line is real-time results. It can be seen form the figure that the results reach a high agreement.By using the NI model interface toolkit, we also build the real-time fuel cell model in the NI PXIe-8135 chassis. The output voltage vi of fuel cell works as the input voltage source for $\mathrm{Z}$ source inverter. And the current $i d c 2$ of $\mathrm{Z}$ source inverter is the input variable of fuel cell model. The simulation time step for the fuel cell model is $500 \mu \mathrm{s}$, whereas for the $\mathrm{Z}$ source inverter is $100 \mathrm{~ns}$.Fig. 20 is the output voltage $v i$ and current $i d c 2$ of fuel cell model. The voltage is between $94 \mathrm{~V}$ and $91 \mathrm{~V}$ with a corresponding current ranging from $13 \mathrm{~A}$ to $35 \mathrm{~A}$. The current and voltage data are collected with the time step of $500 \mu$ s in PXIe-8135 board.

Since the output voltage is about $92 \mathrm{~V}$, according to the shootthrough duty cycle 0.333 , the voltage of the $C_{1}$ should be about $170 \mathrm{~V}$ as can be seen from Fig. 21. Due to the sample time difference in the FPGA and CPU, the voltage from the fuel-cell remains constant within the time step of $500 \mu$ s while the voltage Vc1 will update every $100 \mathrm{~ns}$. Fig. 22 shows the three-phrase current curve of the inverter. The rotor speed is set to $0 \mathrm{rad} / \mathrm{s}$.

\section{Conclusion}

This paper proposed fuel cell electrical vehicle (FCEV) power system models in order to realize an efficient and accurate real-time hardwarein-the-loop simulation. The approach which partitions the electrical vehicle into two independent parts (PEMFC unit and DC-AC converter with electrical motor) leads to the different simulation time steps for each part. As a result, FPGA resources utilization is reduced drastically after implementing the PEMFC model into CPU. The efficiency and 

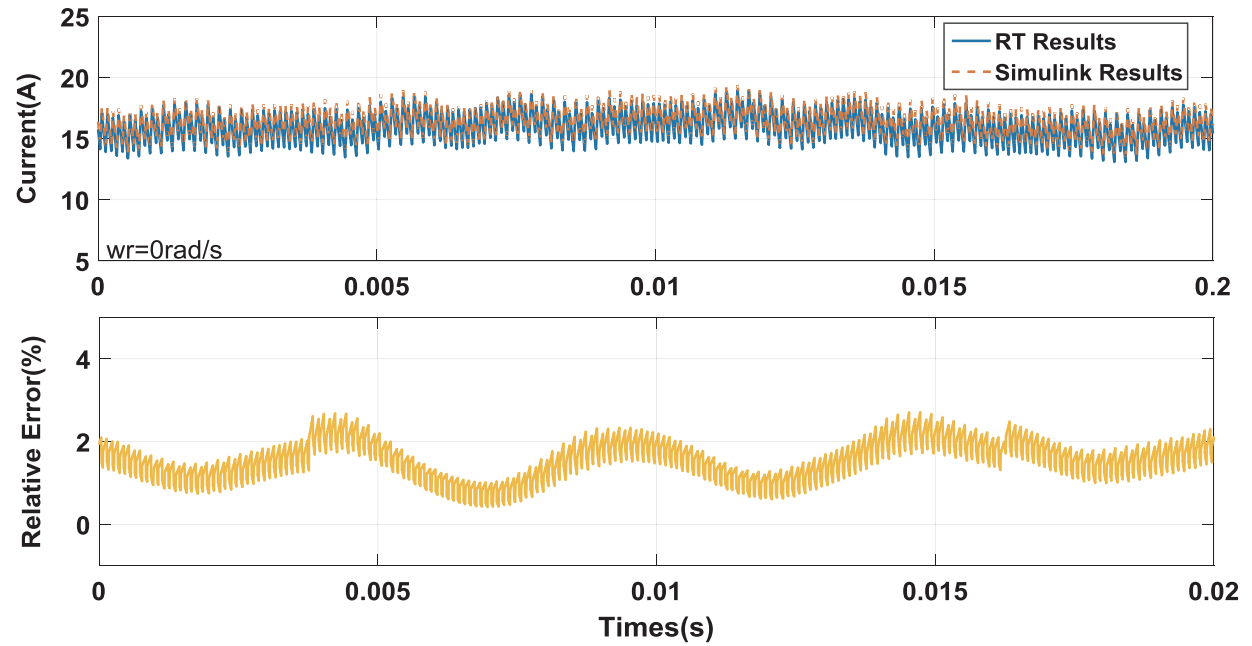

$\left(a_{.0} T / T=0.333\right.$ and the motor speed is set to $0 \mathrm{rad} / \mathrm{s}$ )

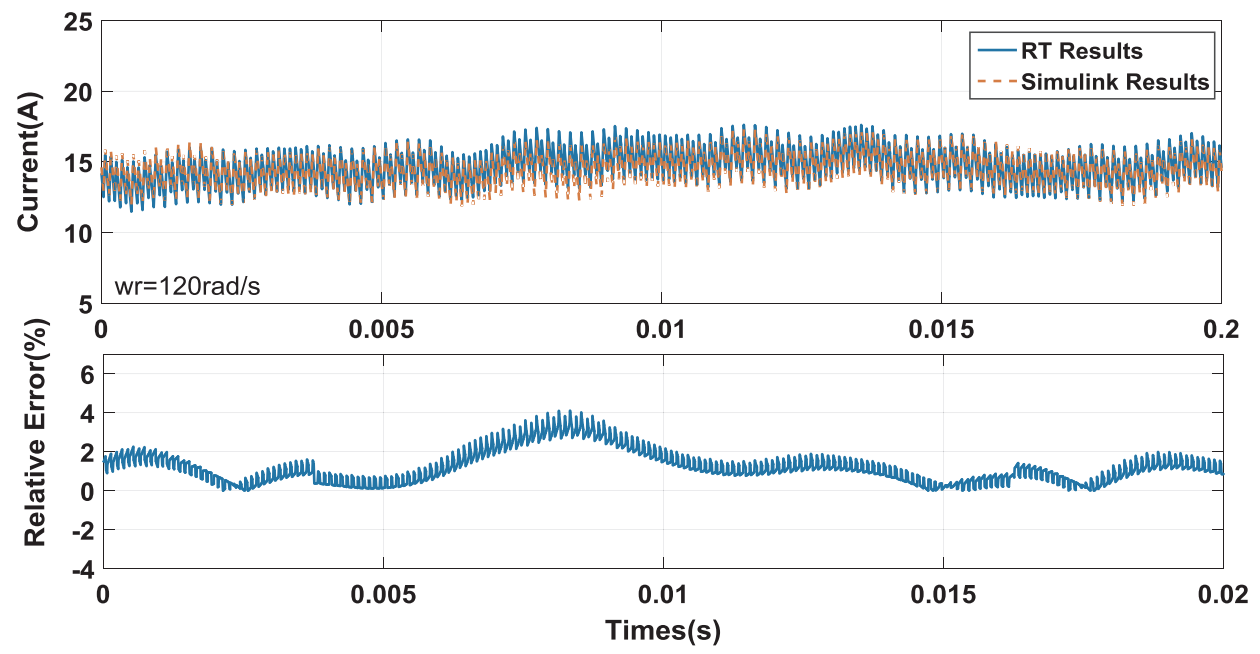

(b. $T_{0} / T=0.333$ and the motor speed is set to $120 \mathrm{rad} / \mathrm{s}$ )

Fig. 18. Real-time simulation results under the shoot-through duty cycle.
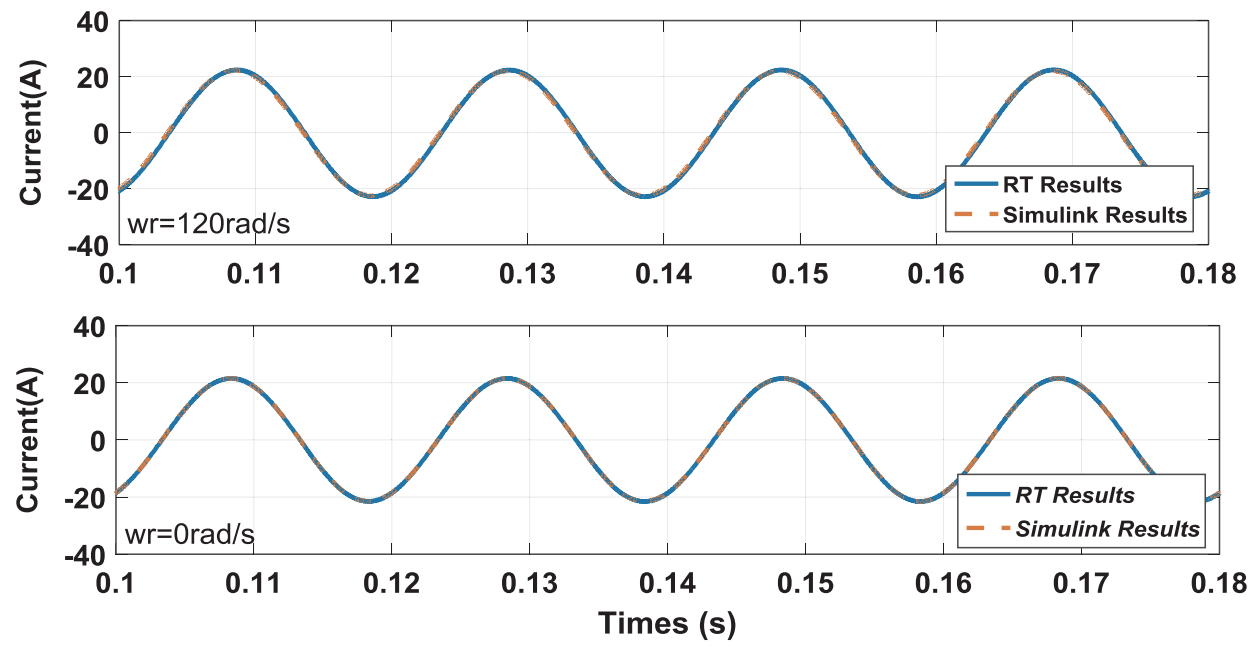

Fig. 19. Real-time simulation results of current in phrase A. 

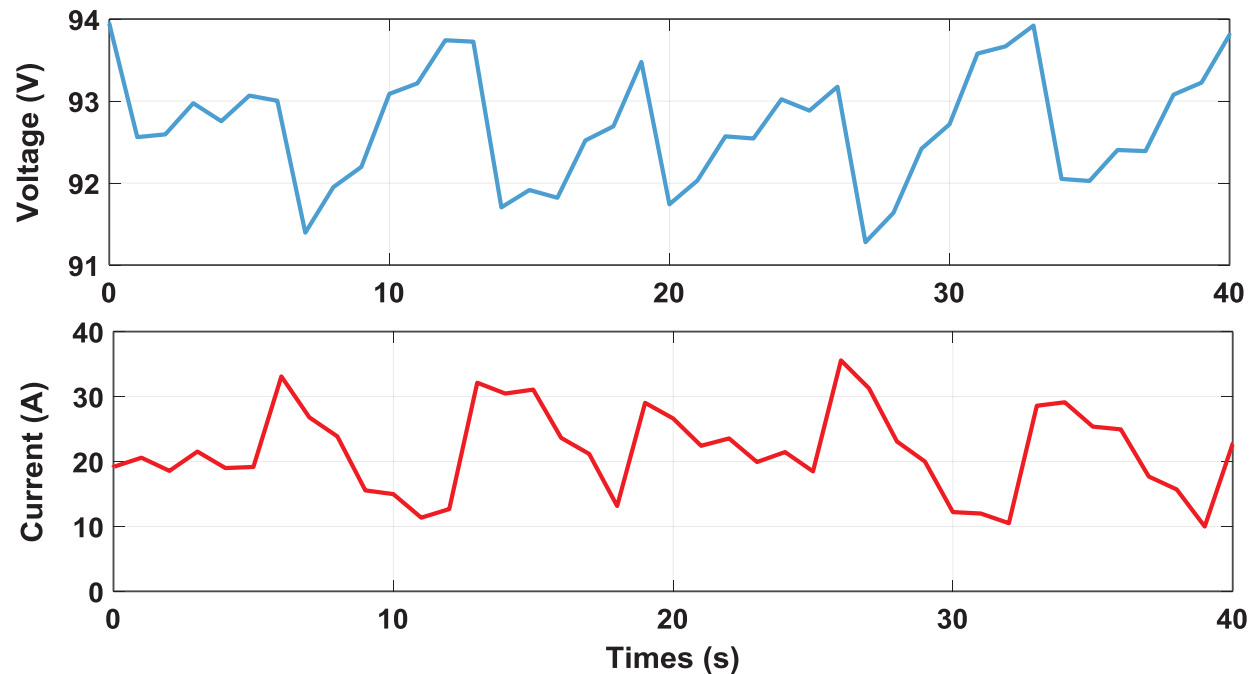

Fig. 20. Fuel cell output voltage and current.

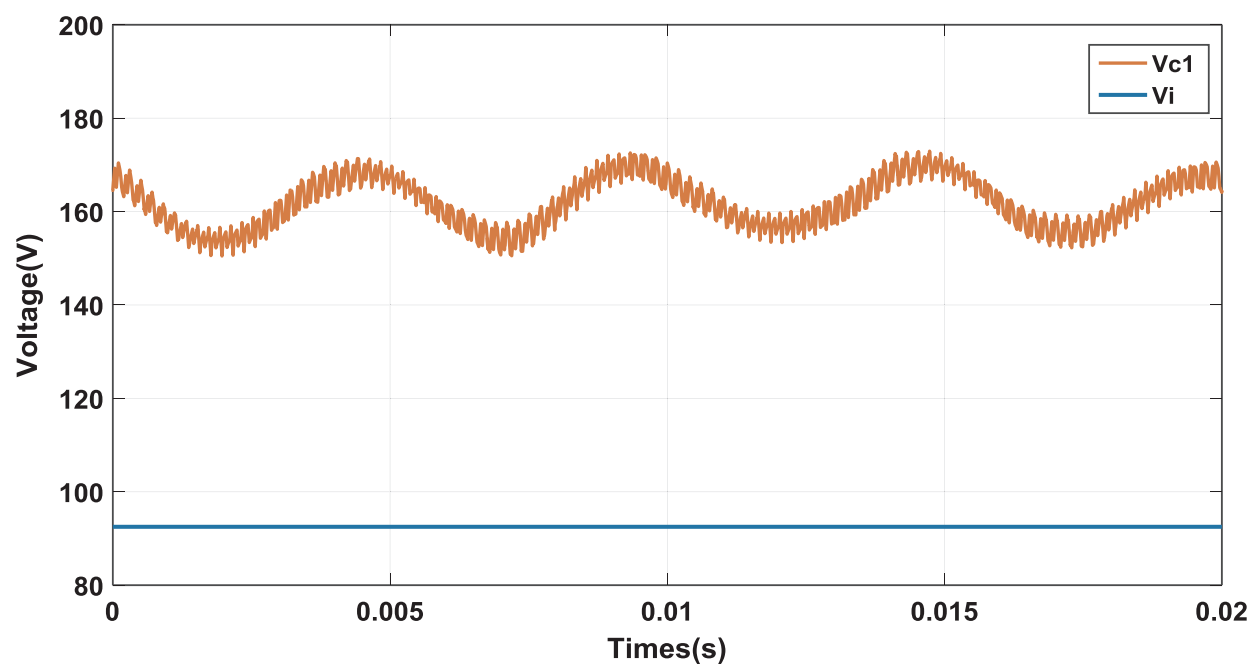

Fig. 21. Current waveform of L1 and voltage waveform of capacitance C1.

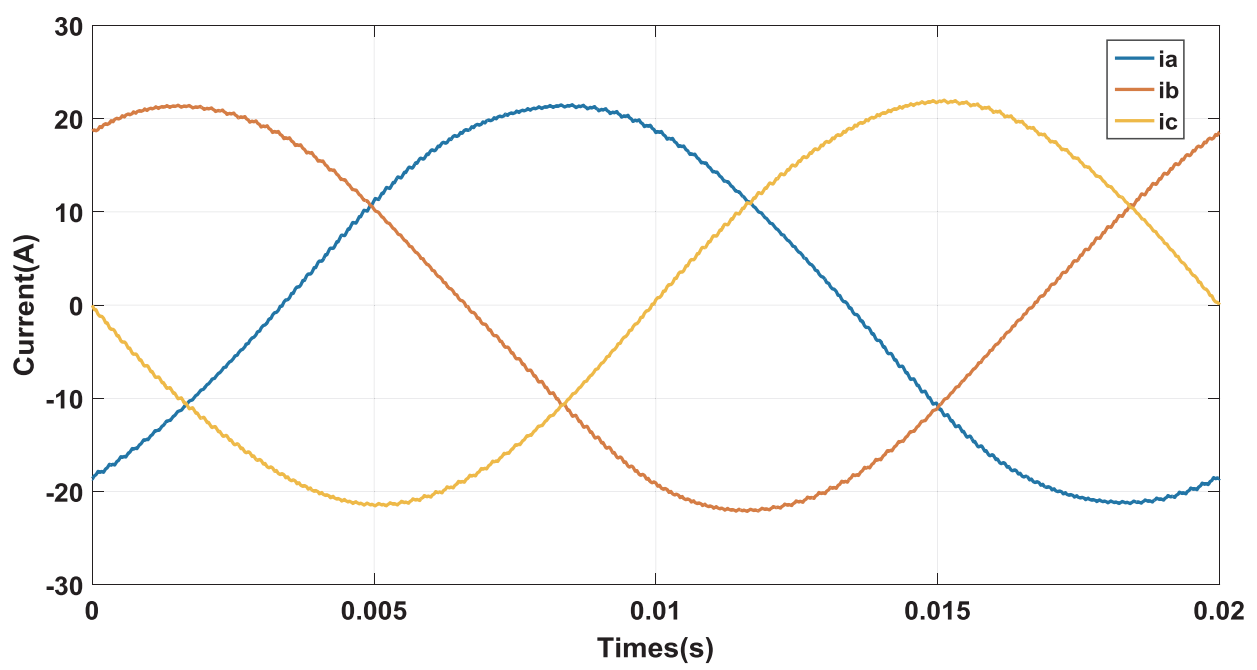

Fig. 22. Current waveform of three phrase current. 
accuracy of FCEV real-time co-simulation are discussed with the following conclusions:

(1) With the Labview model interface toolkit and related NI PXIe-8135 chassis, the multi-physical PEMFC model can be performed and achieve a fast time cycle of $500 \mu \mathrm{s}$.

(2) The power system including a Z source inverter and an electrical motor is implemented based on a Labview FPGA module. A variable topology method is used to take all the combinations of topologies into account. The proposed parallel predictor and corrector simulation time sequence can enable the model simulation time step within $100 \mathrm{~ns}$. The comparisons between the proposed solver and the solver in MATLAB/Simulink indicate that the proposed model can achieve a higher accuracy (e.g. below 1\%).

(3) The proposed CPU-FPGA co-simulation structure provides a versatile and fast solution for testing the FCEV under different operating scenarios without the risk of damaging the actual system.

\section{Acknowledgment}

The authors would like to thank for the support by European Commission H2020 grant ESPESA (H2020-TWINN-2015) EU Grant agreement No: 692224.

\section{References}

[1] Kim J, Lee J, Cho BH. Equivalent circuit modeling of PEM fuel cell degradation combined with a LFRC. IEEE Trans Ind Electron Nov. 2013;60(11):5086-94.

[2] Chang W. Estimating equivalent circuit parameters of proton exchange membrane fuel cell using the current change method. Int J Electr Power Energy Syst 2013;53:584-91.

[3] Wang Caisheng, Nehrir MH, Shaw SR. Dynamic models and model validation for PEM fuel cells using electrical circuits. IEEE Trans Energy Conversion 2005;20(2):442-51.

[4] Giner-Sanz JJ, Ortega EM, Pérez-Herranz V. Mechanistic equivalent circuit modelling of a commercial polymer electrolyte membrane fuel cell. J Power Sources 2018;379(1):328-37.

[5] Sindhuja M, Saravana Kumar N, Sudha V, Harinipriya S. Equivalent circuit modeling of microbial fuel cells using impedance spectroscopy. J Energy Storage 2016;7:136-46.

[6] Reggiani U, Sandrolini L, Giuliattini Burbui GL. Modelling a PEM fuel cell stack with a nonlinear equivalent circuit. J Power Sources 2007;165(1):224-31.

[7] Olivier J, Wasselynck G, Chevalier S, Auvity B, Josset C, Trichet D, et al Multiphysics modeling and optimization of the driving strategy of a light duty fuel cell vehicle. Int J Hydrogen Energy 2017;42(43):26943-55.

[8] Puranik SV, Keyhani A, Khorrami F. State-space modeling of proton exchange membrane fuel cell. IEEE Trans Energy Convers 2010;25(3):804-13.

[9] Gao F, Blunier B, Chrenko D, Bouquain D, Miraoui A. Multirate fuel cell emulation with spatial reduced real-time fuel cell modeling. IEEE Trans Ind Appl 2012;48(4):1127-35.

[10] Murschenhofer D, Kuzdas D, Braun S, Jakubek S. A real-time capable quasi-2D proton exchange membrane fuel cell model. Energy Convers Manage 2018;162:159-75.

[11] Jung JH, Ahmed S, Enjeti P. PEM fuel cell stack model development for real-time simulation applications. IEEE Trans Ind Electron Sept. 2011;58(9):4217-31.

[12] Sedghisigarchi K, Davari A, Famouri P. Dynamic modeling and control of a fuel cell for electric vehicle applications. 2011 IEEE vehicle power and propulsion conference, Chicago, IL 2011. p. 1-5

[13] Das HS, Tan CW, Yatim AHM. Fuel cell hybrid electric vehicles: a review on power conditioning units and topologies. Renew Sustain Energy Rev Sep. 2017;76:268-91.

[14] Wen H, Su B. Hybrid-mode interleaved boost converter design for fuel cell electric vehicles. Energy Convers Manage Aug. 2016;122:477-87.

[15] Rajabzadeh Mahdi, Bathaee Seyed Mohammad Taghi, Golkar Masoud Aliakbar. Dynamic modeling and nonlinear control of fuel cell vehicles with different hybrid power sources. Int J Hydrogen Energy 2016;41(4):3185-98.

[16] El Fadil H, Giri F, Guerrero JM, Tahri A. Modeling and nonlinear control of a fuel cell/supercapacitor hybrid energy storage system for electric vehicles. IEEE Trans Veh Technol 2014;63(7):3011-8.

[17] Gao D, Jin Z, Liu J, Ouyang M. An interleaved step-up/step-down converter for fuel cell vehicle applications. Int J Hydrogen Energy Dec. 2016;41(47):22422-32.

[18] Slah F, Mansour A, Hajer M, Faouzi B. Analysis, modeling and implementation of an interleaved boost DC-DC converter for fuel cell used in electric vehicle. Int J Hydrogen Energy 2017;42(48):28852-64.

[19] Bizon N. Real-time optimization strategy for fuel cell hybrid power sources with load-following control of the fuel or air flow. Energy Convers Manage Feb. 2018;157:13-27.

[20] Benyahia N, Zaouia M, Denoun H, Benamrouche N, Rekiuoa T, Djerdir A. Modeling and characterization of ultra capacitor for fuel cell vehicle simulator. 15th European conference on power electronics and applications (EPE), Lille 2013. p. $1-10$.

[21] Hemi H, Ghouili J, Cheriti A. A real time fuzzy logic power management strategy for a fuel cell vehicle. Energy Convers Manage 2014;80:63-70.

[22] Gao F, Blunier B, Simoes M, Miraoui A. PEM fuel cell stack modeling for real-time emulation in hardware-in-the-loop applications. IEEE Trans Energy Convers 2011;26(1):184-94.

[23] Ma R, Gao F, Breaz E, Huangfu Y, Briois P. Multi-dimensional reversible solid oxide fuel cell modeling for embedded applications. 1-1 IEEE Trans. Energy Convers 2018;PP(99). https://doi.org/10.1109/TEC.2017.2762962.

[24] Fang Zheng Peng. Z-source inverter. IEEE Trans Ind Appl 2003;39(2):504-10.

[25] Peng FZ, Yuan Xiaoming, Fang Xupeng, Qian Zhaoming. Z-source inverter for adjustable speed drives. IEEE Power Electron Lett 2003;1(2):33-5.

[26] Shen M, Wang Jin, Joseph A, Peng FZ, Tolbert LM, Adams DJ. Maximum constant boost control of the Z-source inverter. 39th IAS annual meeting conference record of the 2004 IEEE industry applications conference 2004. pp. 147.

[27] Krause PC, Wasynczuk O, Sudhoff SD. Analysis of electric machinery. IEEE Press; 2002.

[28] Mohan N, Undeland TM, Robbins WP. Power electronics: converters, applications, and design. New York: John Wiley \& Sons Inc; 1995. Section 8.4.1.

[29] Liu Chen, Ma Rui, Bai Hao, Gechter Franck, Gao Fei. A new approach for FPGAbased real-time simulation of power electronic system with no simulation latency in subsystem partitioning. Int J Electr Power Energy Syst 2018;99:650-8.

[30] LabVIEW. Model interface toolkit readme; 2015. http://www.ni.com/pdf/manuals/ 375381a.html.

[31] NI FPGA module for PXI express. http://www.ni.com/fpga/f/.

[32] NI PXIe-7975R. NI FlexRIO ${ }^{\mathrm{m} M}$ FPGA Module for PXI Express. http://www.ni.com/ pdf/manuals/373980d.pdf.

[33] Breaz Elena, et al. A short review of aging mechanism modeling of proton exchange membrane fuel cell in transportation applications. IECON 2014-40th annual conference of the IEEE industrial electronics society 2014.

[34] Wu Y, Breaz E, Gao F, Paire D, Miraoui A. Nonlinear performance degradation prediction of proton exchange membrane fuel cells using relevance vector machine. IEEE Trans Energy Convers 2016:31(4):1570-82.

[35] Wu Y, Breaz E, Gao F, Miraoui A. A modified relevance vector machine for PEM fuel-cell stack aging prediction. IEEE Trans Ind Appl 2016;52(3):2573-81.

[36] Huangfu Yigeng, et al. Transient dynamic and modeling parameter sensitivity analysis of 1D solid oxide fuel cell model. Energy Convers Manage 2013;71:172-85.

[37] Zhao Dongdong, et al. Study of the modeling parameter effects on the polarization characteristics of the PEM fuel cell. Int J Hydrogen Energy 2016;41(47):22316-27.

[38] Zhao Dongdong, et al. Parameter sensitivity analysis and local temperature distribution effect for a PEMFC system. IEEE Trans Energy Convers 2015;30(3):1008-18. 